\title{
Fullerene-capped Copolymers and P3HT: PCBM Bulk Heterojunctions: Device Stability and Efficiency Improvements
}

Mahfoudh Raïssi, ${ }^{\text {1a }}$ Harikrishna Erothu, ${ }^{2,3}$ Emmanuel Ibarboure, ${ }^{2,3}$ Henri Cramail, ${ }^{2,3}$ Laurence Vignau, ${ }^{1 *}$ Eric Cloutet, ${ }^{2,3 *}$ Roger C. Hiorns ${ }^{2,3 b *}$

1 Université de Bordeaux, Laboratoire de l'Intégration du Matériau au Système (IMS), CNRS (UMR 5218), ENSCBP, IPB, 16 avenue Pey Berland, 33607 Pessac Cedex, France.

2 Université de Bordeaux, Laboratoire de Chimie des Polymères Organiques (LCPO), (UMR 5629), ENSCBP, IPB, 16 avenue Pey Berland, 33607 Pessac Cedex, France.

3 CNRS, Laboratoire de Chimie des Polymères Organiques (LCPO), (UMR 5629), ENSCBP, IPB, 16 avenue Pey Berland, 33607 Pessac Cedex, France.

a Current address: XLIM, Optoplast, 123 Avenue Albert Thomas, 87060, Limoges Cedex, France

b Current address: CNRS, IPREM (EPCP, UMR 5254), 2 avenue Président Angot, 64053 Pau, France.

E-mail: Laurence.vignau@ims-bordeaux.fr; eric.cloutet@enscbp.fr; roger.hiorns@univ-pau.fr

\begin{abstract}
A fullerene end-capped polymer-compatibilizer based on poly(3-hexylthiophene) (P3HT) was synthesized and demonstrated to have a remarkable effect on both the stability and efficiency of devices made from exemplar P3HT and [6,6]-phenyl $\mathrm{C}_{61}$-butyric acid methyl ester (PCBM). P3HT with ethynyl chain-ends and $\alpha$-azido- $\omega$-bromo-PS were prepared via Grignard metathesis (GRIM) and atom transfer radical polymerisations, respectively. "Click" chemistry resulted in the preparation of poly(3-hexylthiophene)-block- $\omega$-bromo-polystyrene (P3HT- $b$-PS-Br), and subsequent atom transfer radical addition chemistry with fullerene $\left(\mathrm{C}_{60}\right)$ yielded the donor-acceptor block copolymer P3HT- $b$-PS-C60. Both P3HT- $b$-PS-Br and P3HT$b$-PS-C60 were considered as compatibilizers with P3HT/PCBM blends, with the study detailing effects on active-layer morphology, device efficiency and stability. When used at low concentrations, both P3HT- $b$-PS-Br $(1 \%)$ and P3HT- $b$-PS-C60 $(0.5 \%)$ resulted in considerable $28 \%$ and $35 \%$ increases in efficiencies with respect to devices made from P3HT/PCBM alone. Furthermore, P3HT- $b$-PS-C60 (0.5\%) resulted in an important improvement in device stability.
\end{abstract}




\section{Introduction}

Solar cells using polymers in the active layer offer considerable advantages as they are cheap, printable, near-transparent, colourful, and compatible with flexible substrates and light-weight applications. Their fabrication by high-throughput, roll-to-roll processes makes them a promising photovoltaic technology. ${ }^{1-5}$ Today, the main challenges consist in increasing stability while retaining, or better, improving device efficiencies. ${ }^{6,7}$ For cells based on bulkheterojunctions (BHJs), it is critical to prevent charge recombination, while enhancing chargetransfer and collection. ${ }^{8-10}$ The polymer active layer should exhibit a bicontinuous network with domain widths close to the exciton-diffusion length and high donor acceptor interfacial areas to respectively favour exciton-dissociation and charge-transport. BHJs based on the exemplar poly(3-hexylthiophene):phenyl-C61-butyric acid methyl ester (P3HT:PCBM) give efficiencies in the range of 3-5\%. ${ }^{11}$ Despite continuous improvements in efficiencies, for example by replacing P3HT with low-band gap polymers, there remain two major drawbacks: a poorly controlled electron donor (D)/acceptor (A) domain size distribution and the inherent thermal morphological instabilities. As phase separation in BHJ active layers is governed by thermodynamics, it is difficult to control experimentally, and the final structure contains phases with a distribution of sizes (due to coarsening and nucleation effects) which heavily impact on the device properties. ${ }^{12}$ The BHJ may be stabilized by varying the ratios of the components, solvents, casting methods, thermal or solvent annealing, and by using solvent and molecular additives. ${ }^{13-20}$

Block copolymers have been identified as particularly promising materials for tuning microphase separation in BHJs. ${ }^{21-23}$ One block is commonly of the same nature as the donor semiconducting polymer while the second may vary with respect desirable functionalities. Specifically, the amphiphilic nature of block copolymers and their ability to self-assemble into highly ordered and thermodynamically stable mesostructures render them attractive for tailoring BHJ morphologies. ${ }^{24-31}$ Sommer et al., ${ }^{32}$ Sary et al., ${ }^{33}$ and Mingu et al. ${ }^{34}$ reported an enhancement of phase separation and thermal stability, as well as increased internal quantum efficiencies, by employing rod-coil, donor-acceptor, block copolymers as compatibilizers. Renaud et al. reported a systematic investigation of the photovoltaic performance in P3HT:PCBM-based solar cell devices when a tailored poly(3-hexylthiophene)-block-poly(4vinylpyridine) (P3HT- $b$-P4VP) polymer was added as a nano-structuring agent. ${ }^{35}$ The power conversion efficiency (PCE) reached a plateau of $3.4 \%$ with P3HT- $b$-P4VP at $4 \% \mathrm{w} / \mathrm{w}$ without solvent or thermal annealing. After a thermal annealing treatment, the PCE increased to $4.3 \%$. They demonstrated that improvements were due to the formation of a well- 
optimized nanoscale structure. Sun et al. ${ }^{36}$ showed that adding poly(3-hexythiophene)-blockpolystyrene (P3HT- $b$-PS) to P3HT:PCBM blends increased the crystallinity of P3HT and homogenized the vertical distribution of P3HT and PCBM in the active layer. They attributed these outcomes to the favourable interactions of the P3HT block with the P3HT homopolymer and the strong affinity of the PS block toward PCBM, which led to enhanced holetransport/charge extraction and absorption range. As a consequence, the device efficiency was improved by $35 \%$ with the addition of $5 \mathrm{wt} \%$ P3HT- $b$-PS or $7 \mathrm{wt} \%$ P3HT- $b$-PI to the active layer. ${ }^{36,37}$ Similarly, Yang et al. ${ }^{38}$ showed that adding 5\% donor:acceptor diblock copolymer based on P3HT containing $\mathrm{C}_{60}$ led to $30 \%$ higher efficiency compared with that of P3HT:PCBM alone. Such materials would be expected to considerably stabilise the active layer morphology due to increased compatibilities between respective blocks and domains. While numerous works have looked at polymers with grafted, pendent $\mathrm{C}_{60}$, relatively few have dealt with chain-end $\mathrm{C}_{60} .{ }^{39}$ Facile routes do exist to the atom transfer radical addition of brominated PS to $\mathrm{C}_{60}$, as demonstrated by $\mathrm{Li}^{40,41}$ and Mathis. ${ }^{42,43}$

In this context, we compare the use of P3HT- $b$-PS and P3HT- $b$-PS-C60 as additives in P3HT:PCBM blends and evaluate the improvement of both the stability and the powerconversion efficiency of P3HT:PCBM-based solar cells. The structures of P3HT- $b$-PS and P3HT- $b$-PS-C60 are shown in Scheme 1. It is demonstrated that both materials, to varying degrees and in small proportions, compatibilise P3HT-blend-PCBM leading to well-organised structures, that support improved device efficiencies and stabilities. It is hoped that this system will encourage further developments in analogous low-band gap polymers.

\section{Experimental details}

\section{Materials}

All solvents were used as distilled from over their respective drying agents. All chemicals were received from Aldrich and used as received unless specified. ${ }^{1} \mathrm{H}(400 \mathrm{MHz})$ and ${ }^{13} \mathrm{C}$ (100 MHz) NMR spectra were recorded on a Bruker ${ }^{\circledR}$ Avance 400 spectrometer at ambient temperature in $\mathrm{CDCl}_{3}$. Size exclusion chromatography (SEC) was performed using THF as eluant at $35{ }^{\circ} \mathrm{C}$ and flow rate of $1 \mathrm{~mL} \mathrm{~min}^{-1}$ through 4 columns [TSK G5000HXL $(9 \mu \mathrm{m})$, G4000HXL $(6 \mu \mathrm{m})$, G3000HXL $(6 \mu \mathrm{m})$, and G2000HXL $(5 \mu \mathrm{m})]$ connected to Varian refractometer and UV-visible spectrophotometer calibrated against linear polystyrene standards. Further equipment is detailed in the Supporting Information. 


\section{P3HT-b-PS-Br}

$\omega$-Ethynyl-P3HT (219 mg, $0.022 \mathrm{mmol}), \alpha$-azido- $\omega$-bromo-PS (280 mg, $0.073 \mathrm{mmol}), \mathrm{CuI}$ (40 mg, $0.210 \mathrm{mmol}$ ), DIPEA (diisopropylethylamine, $565 \mathrm{mg}, 4.38 \mathrm{mmol}$ ) and THF (30 mL) were introduced in to a $50 \mathrm{~mL}$ round-bottom flask, evacuated for $10 \mathrm{~min}$ and backfilled with nitrogen ( 3 cycles). Then the reaction mixture was subjected for sonication $(2 \mathrm{~h})$ to aid $\omega$ ethynyl-P3HT dissolution in THF (clear orange solution) and the flask placed in a constant temperature oil bath at $50{ }^{\circ} \mathrm{C}$ for 5 days. The solution was passed through a neutral alumina column in order to remove copper salt. After concentration, the product was recovered by precipitation in methanol, dried under reduced pressure, and then three times dissolved in a minimum of THF and precipitated in acetone to remove unreacted PS and low molar mass P3HT. Further overnight drying under reduced pressure yielded pure copolymer. SEC (THF, $\left.35{ }^{\circ} \mathrm{C}, 254 \mathrm{~nm}\right) M_{\mathrm{n}}=14900 \mathrm{~g} \mathrm{~mol}^{-1}$ and $Ð=1.27 .{ }^{1} \mathrm{H} \mathrm{NMR}\left(400 \mathrm{MHz}, \mathrm{CDCl}_{3}\right) \delta_{\mathrm{H}:} 7.52(\mathrm{~s}$, $=[\mathrm{CH}]-\mathrm{N}), 7.0-7.2(\mathrm{~m}, \mathrm{Ar}, \mathrm{PS}), 6.97$ (s, Ar, thiophenyl), 6.3-6.7 (m, Ar, PS), $3.74(\mathrm{~m},=\mathrm{N}-$ $\mathrm{CH}_{2}$ - and - $\left.\mathrm{O}-\mathrm{CH}_{2}\right), 2.7$ (m, - $\mathrm{CH}_{2}-$ ), 2.54 (m, - $\mathrm{CH}_{2}$, chain-end), 1.1-2.0 (m, - $\mathrm{CH}_{2}$ ), 0.9 (t, $\left.\mathrm{CH}_{3}\right) \mathrm{ppm}$.

\section{P3HT-block-PS-C 60}

$\mathrm{C}_{60}(28 \mathrm{mg}, 0.039 \mathrm{mmol}), \mathrm{CuBr}(12 \mathrm{mg}, 0.084 \mathrm{mmol}), 2,2$ '-bipyridine (26 mg, $\left.0.017 \mathrm{mmol}\right)$ and P3HT-block-PS-Br (91 mg, $0.0065 \mathrm{mmol}$ ) were introduced to a $50 \mathrm{~mL}$ round-bottom flask and dissolved in $20 \mathrm{~mL}$ of chlorobenzene (freshly distilled over $\mathrm{CaH}_{2}$ ). The mixture was stirred for $5 \mathrm{~min}$ and degassed three times by freeze-pump-thaw cycles to remove residual oxygen. Then the reaction was performed at $110{ }^{\circ} \mathrm{C}$ for $24 \mathrm{~h}$. The mixture was dropped into THF $(200 \mathrm{~mL})$ to precipitate unreacted fullerene that was then removed along with copper salts by passing the solution through a neutral alumina column. Once precipitated from THF in excess methanol, the polymer was recovered by filtration, redissolved in THF and again passed through a fresh column. This procedure was repeated three times, following precipitation in methanol and dried under reduced pressure at $40{ }^{\circ} \mathrm{C}$ for 3 days yielded pure C60-attached copolymer P3HT-block-PS-C60. SEC (THF, $\left.35{ }^{\circ} \mathrm{C}, 254 \mathrm{~nm}\right) M_{\mathrm{n}}=15400 \mathrm{~g} \mathrm{~mol}^{-1}$ and $Ð=1.43 . \delta_{\mathrm{H}} 7.52(\mathrm{~s},=[\mathrm{CH}]-\mathrm{N}), 7.0-7.2(\mathrm{~m}, \mathrm{Ar}, \mathrm{PS}), 6.97(\mathrm{~s}, \mathrm{Ar}$, thiophenyl), 6.3-6.7 (m, Ar, PS), 3.74 (m, =N-CH${ }_{2}$ and -O-CH2), 2.7 (m, - $\mathrm{CH}_{2-}$ ), 2.54 (m, $-\mathrm{CH}_{2-}$, chain-end), 1.1-2.0 (m, $\left.-\mathrm{CH}_{2}-\right), 0.9\left(\mathrm{t},-\mathrm{CH}_{3}\right) \mathrm{ppm}$. 
Other synthetic routes to the chemicals shown in Schemes 1 and 2 are detailed in the Supporting Information along with the relevant characterisations.

\section{Solar Cell Preparations}

Glass/ITO substrates were cleaned using ethanol, acetone and isopropanol, and exposed to a $\mathrm{UV}-\mathrm{O}_{3}$ plasma for $15 \mathrm{~min}$. A thin layer of PEDOT:PSS was spin-coated at $5000 \mathrm{rpm}$ and dried in an oven at $110{ }^{\circ} \mathrm{C}$ under a rotary pump vacuum for $1 \mathrm{~h}$. The thickness of the PEDOT:PSS layer was $50 \mathrm{~nm}$ as measured by an Alpha-step IQ surface profilometer. All procedures after PEDOT:PSS deposition were performed in an inert-atmosphere $\left(\mathrm{N}_{2}\right)$ in a glovebox $\left(\mathrm{O}_{2}\right.$ and $\left.\mathrm{H}_{2} \mathrm{O}<0.1 \mathrm{ppm}\right)$. Subsequently, the photoactive layer was prepared from a solution of P3HT (20 mg mL $\left.\mathrm{mL}^{-1}\right)$ and PCBM (20 mg mL $\left.\mathrm{mL}^{-1}\right)$ in $o$-dichlorobenzene (DCB). Then the P3HT:PCBM blend with different ratios $(0 \%$ to $5 \%)$ of each additive (P3HT- $b$-PS and P3HT- $b$-PS-C 60 ) was spin-coated on top of the PEDOT:PSS layer. The thickness of the photoactive layer was typically in the range of 100-150 $\mathrm{nm}$. The aluminium electrode was thermally deposited $(100 \mathrm{~nm})$ through a shadow mask with an average pressure of $2 \times 10^{-6}$ mbar. Thermal annealing treatment was performed after aluminium electrode deposition (post annealing treatment) on a temperature-controlled hot plate at $165^{\circ} \mathrm{C}$ for $10 \mathrm{~min}$. Devices were left to cool down to room temperature before testing. Current-voltage characteristics were recorded using a Keithley $4200 \mathrm{SCS}$, under an illumination of $100 \mathrm{~mW} \mathrm{~cm}^{-2}$ from a KHS Solar Cell test 575 solar simulator with AM1.5G filters. Four $8.6 \mathrm{~mm}^{2}$ photovoltaic cells were fabricated on each $15 \times 15 \mathrm{~mm}^{2}$ substrate. In order to check the repeatability of the characteristics, the measurements were performed on 16 different devices.

\section{AFM and TEM characterisations}

All thin films were first observed with AFM, which does not damage the samples, followed by TEM. AFM images were recorded in air at room temperature with a Nanoscope IIIa microscope operating in tapping mode. The probes were commercially available as silicon tips with a spring constant of $42 \mathrm{Nm}^{-1}$, resonance frequency of $285 \mathrm{kHz}$, and a typical radius of curvature in the 10-12 nm range. The measurements were carried out at specific positions of the sample with different scan sizes (typically 1, 3 and $5 \mu \mathrm{m}$ ). Each scanned micrograph consists of 512 lines. Images were taken continuously with a scan rate of $1.0 \mathrm{~Hz}$. The preparation of the AFM samples was performed by peeling off the aluminium electrode partially covering the active layer. AFM characterization was also conducted on the areas not covered by the aluminium electrode in order to exclude any morphological damage induced 
by this process. Following AFM measurements, the active layer films were collected from the devices for further TEM observations. For that purpose, the devices were immersed into deionized water to dissolve PEDOT:PSS and allow the blend film to float. It was then collected and placed on a 400 square-mesh copper TEM grid (Agar Sci., Inc.). As spatial resolution obtained under focused conditions is limited, ${ }^{44,45}$ images were taken under slightly defocused (i.e., phase contrast) conditions to better visualize the fibres, rods, and networks of the constituents. For example, in bright-field TEM under these particular experimental conditions, P3HT nanorods appear bright, and PCBM-rich regions appear dark because of the lower density of P3HT crystals $\left(1.1 \mathrm{~g} \mathrm{~cm}^{-3}\right)$ as compared to PCBM $\left(1.5 \mathrm{~g} \mathrm{~cm}^{-3}\right){ }^{45-49}$

\section{Results and Discussion}

\section{Synthesis of block copolymers}

Appropriately terminated P3HT, of predeterminable molecular weight, was prepared through in-situ functionalization of an active GRIM chain-growth polymerisation of dibromo-3hexylthiophene, ${ }^{50}$ to give $\omega$-ethynyl-P3HT in high yield. ${ }^{51,52}$ The ${ }^{1} \mathrm{H}$ NMR of $\omega$-ethynylP3HT (Fig. S4) shows the typical peaks associated with regioregular P3HT ( ca 97\%) along with a minor peak at $3.52 \mathrm{ppm}$ due to the ethynyl chain-ends, similarly confirmed by ${ }^{13} \mathrm{C}$ NMR (Fig. S5) with a small peak at 68.0 ppm. MALDI-TOF characterisations (Fig. S6) showed, as expected, ${ }^{51}$ that a minor proportion $(21 \%)$ of macromolecules carried two ethynylated chain-ends, and therefore it should be remembered in the ensuing "click" chemistry described below that a mixture of P3HT- $b$-PS and PS- $b$-P3HT- $b$-PS was formed. The SEC of $\omega$-ethynyl-P3HT (Fig. 1) indicated $M_{\mathrm{n}}=14000 \mathrm{~g} \mathrm{~mol}^{-1}$ and dispersity, $Ð=$ $M_{\mathrm{n}} / M_{\mathrm{w}}=1.1$. Given that these values are against polystyrene standards, to obtain the "real" molar mass, a coefficient of around 2 should be used, ${ }^{53}$ thus giving $M_{\mathrm{n}}(\omega$-ethynyl-P3HT) $=$ $7000 \mathrm{~g} \mathrm{~mol}^{-1}$ (i.e., equal to $\mathrm{ca} 40$ repeating units).

To obtain a PS with the appropriate azido-group, the ATRP initiator was prepared as in Scheme 2. Synthetic details are given in the Supporting Information. It is worth noting that the preparation of the intermediate 3-azido-1-propanol from 3-bromo-propanol using sodium azide in accordance with a literature procedure gave low yields (15\%) in our hands. ${ }^{54}$ However, performing the reaction in the presence of dicyclohexano-18-crown- 6 and butanone, as suggested by Fernandez-Santana, ${ }^{55}$ raised yields to around $83 \%$ due to the improved nucleophilic activity of the azide anion. ${ }^{56}$ Furthermore, in preparing the initiator, 3azidopropyl-2-bromoisobutyrate from our 3-azido-1-propanol, we found that the literature 
procedure $^{57}$ gave rise to an inseparable mixture of the product and a reagent, acyl bromide, even having tried various ratios of mixed eluents of dichloromethane, toluene, ethyl acetate, hexane, or ethyl acetate with little success in our lab. We found changing down the ratio of excess acyl bromide to 3-azido-1-propanol from 1.5 equivalents to 1.1 resulted in a good yield of $81 \%$.

$\alpha$-Azido- $\omega$-bromo-polystyrenes of various molar masses were synthesized following the protocol given in the SI, and as indicated in Table S1. The reaction was performed at 130 ${ }^{\circ} \mathrm{C}$ with a normal $\mathrm{CuBr} /$ bipyridine catalytic system (Scheme 1), there being no interference between atom transfer radical polymerizations (ATRP) and azide groups, ${ }^{58}$ and stopped abruptly by lowering the temperature to $0{ }^{\circ} \mathrm{C}$. Short reaction times were preferred with low conversions in order to avoid secondary reactions and retain PS-Br chain-ends. Figures S11 and S12 show the ${ }^{1} \mathrm{H}$ and ${ }^{13} \mathrm{C}$ NMRs respectively of $\alpha$-azido- $\omega$-bromo-polystyrenes with peaks in accordance with expectation. Infra-red spectroscopy confirmed the presence of azide groups by way of the expected absorption at $c a 2100 \mathrm{~cm}^{-1}$ (see Figure S12).

The synthesis of P3HT- $b$-PS diblock copolymers exploits robust "click" methodologies. ${ }^{59}$ The reaction between $\omega$-ethynyl-P3HT and $\alpha$-azido-PS was successfully achieved through modifying prior work. ${ }^{52}$ It is worth noting that $\omega$-ethynyl-P3HT displayed a much lower reactivity towards "click" chemistry than P3HTs with ethynyl groups separated from the P3HT by alkyl chains, most likely due to conjugation with the main chain (see Fig. S15). Taking inspiration from references 60-62 that showed that it is possible to obtain copolymers from ethynyl-conjugates by varying conditions, we optimized conditions using $\mathrm{CuI}$ and Hunig's base diisopropylethylamine $\left[(i \text {-pr })_{2} \mathrm{NEt}\right.$, DIEA or DIPEA] in THF at $50{ }^{\circ} \mathrm{C}$. Sonication was found to be particularly important to ensure full solvation of the $\omega$-ethynylP3HT prior to chemistry.

The diblock copolymers obtained were characterized by SEC (Fig. 1), infrared spectroscopy (Fig. S14) and ${ }^{1}$ H NMR (Fig. 2 and Fig. S15). The SEC chromatograms showed an increase in molar mass, however, it was a relatively small shift toward lower elution times. This would be expected due to the change in the exclusion behaviour of the macromolecules in going from rigid P3HTs to a rod-coil structure. Thus P3HT of indicated molar mass 14000 $\mathrm{g} \mathrm{mol}^{-1}$ and probable real mass of $c a 7000 \mathrm{~g} \mathrm{~mol}^{-1}$ with $\alpha$-azido- $\omega$-bromo-PS $\left(M_{\mathrm{n}}=3800, Ð=\right.$ 1.17) yielded the product P3HT- $b$-PS of indicated molar mass $14900 \mathrm{~g} \mathrm{~mol}^{-1}$ and $Ð=1.27$. It is notable, however, that the SEC of $\omega$-ethynyl-P3HT carries a small portion of P3HT with a molar mass double that of main material. This is associated with disproportionation of the $\mathrm{Ni}$ catalyst through the reaction with water present in the $5 \mathrm{M} \mathrm{HCl}$ of the termination step and the 
coupling of P3HT chains. ${ }^{63}$ That the area of the corresponding peak increases greatly on reaction with $\alpha$-azido- $\omega$-bromo-PS confirms the presence of PS-P3HT-PS by this process and also that of the reaction of the portion ( $c$ a 21\%) of $\alpha$-diethynyl-P3HT in the $\omega$-ethynylP3HT sample. FT-IR (Fig. S14) confirmed the formation of P3HT- $b$-PS by way of the removal of the peak at $2100 \mathrm{~cm}^{-1}$ corresponding to the azide function. In the NMR the expected peaks for P3HT and PS are found, while the peak at $3.52 \mathrm{ppm}$ due to the ethynyl group (see Fig. S11) has disappeared. A new peak at $7.51 \mathrm{ppm}$ corresponding to the formation of triazole ring (proton $\mathbf{f}$ ) demonstrates the cycloaddition in both the NMRs of P3HT- $b$-PS and P3HT- $b$-PS-C60 (see Fig. S15).

P3HT- $b$-PS-C60 was prepared as shown in Scheme 1. The work by Zhou et al. on the mono-addition of PS-Br to $\mathrm{C}_{60}$ was of particular use. ${ }^{64}$ In order to reduce the possibility of bis-additions to the $\mathrm{C}_{60}$, by way of the formation of a weak PS- $\mathrm{C}_{60}-\mathrm{Br}$ intermediate, the reaction was performed in chlorobenzene with a high excess of $\mathrm{C}_{60}$. A slight increase in the $M_{\mathrm{n}}$ was found from 14900 to $15400 \mathrm{~g} \mathrm{~mol}^{-1}$ in going from P3HT-block-PS to P3HT-block-PS$\mathrm{C}_{60}$ (see Fig. 1) in accordance with expectations. ${ }^{1} \mathrm{H}$ NMR and ${ }^{13} \mathrm{C}$ NMR proved not particularly useful due to the low concentration of $\mathrm{Br}$ and $\mathrm{C}_{60}$ at chain ends. It is interesting to note, however, that the ${ }^{1} \mathrm{H}$ NMRs of P3HT-block-PS and P3HT-block-PS-C60 (Figs. 2 and $\mathrm{S} 15$, respectively) are exactly the same, except for minor peaks appearing in the 2-3 ppm region, most likely due to methine and methylene protons at the chain-end close to $\mathrm{C}_{60}$. Clearer, diagnostic evidence for the addition of $\mathrm{C}_{60}$ was found though the UV-visible absorption spectra of P3HT-block-PS and P3HT-block-PS-C 60 overlaid in Fig. S16. Here we find the characteristic peaks due to P3HT at $c a 520,550$ and $600 \mathrm{~nm}$, and PS at $c a 260 \mathrm{~nm}$, ${ }^{65}$ with a peak due to $\mathrm{C}_{60}$ only for P3HT-block-PS-C 60 at $c a 330 \mathrm{~nm}^{6}{ }^{66}$

DSC was used to find out the effect of the attachment of $\mathrm{C}_{60}$ on the crystallization of P3HT. Fig S13 indicates the expectedly low $T_{\mathrm{g}}$ at $88^{\circ} \mathrm{C}$ for the PS given its low molar mass. Fig. S17 though shows the strongly characteristic DSC thermogram of P3HT along with those of P3HT- $b$-PS, and P3HT- $b$-PS-C 60 . There is a clear decrease in melting $\left(T_{\mathrm{m}}\right)$ and crystallization temperatures $\left(T_{\mathrm{c}}\right)$ in that order due to the macromolecular disruption caused by the PS and then by the PS- $\mathrm{C}_{60}$, as detailed in Table 1.

\section{Optical characterisations of thin films}

Fig. 3 shows the UV-visible absorption spectra of P3HT- $b$-PS and P3HT:PCBM (1:1) films with different ratios of P3HT- $b$-PS cast from $o$-DCB and annealed at $165^{\circ} \mathrm{C}$ for 10 minutes in 
a glovebox. We notice two absorption bands at 263 and $330 \mathrm{~nm}$ that are attributed to PCBM, as observed by Urien et al. ${ }^{18}$ While the absorption peaks at 506 and $553 \mathrm{~nm}$ are attributed to the absorption bands of P3HT. The intensity of the P3HT absorption band slightly increases with $1 \mathrm{wt} \%$ additive, indicating increasing crystallisation. This absorption decreases as the fraction of copolymer additive was further increased, indicative of a small decrease in the optical density of the film and suggests less densely-packed polymer chains in the crystalline phase. ${ }^{67}$ Similarly, Figs 3(c and d) show the UV-visible absorption spectrum of the additive P3HT- $b$-PS-C 60 alone then as mixed with P3HT:PCBM (1:1) at varying ratios and under similar conditions. We note that the intensity of the PCBM absorption bands (260 and 340 $\mathrm{nm}$ ) increasing with $0.5 \mathrm{wt} \%$ additive, indicating the presence of more PCBM domains, which in turn slightly decrease with increasing the additive concentration. This relation shows a small decrease in the optical density of the film and suggests the formation PCBM aggregates. ${ }^{49,67-68}$

\section{AFM and TEM characterisations}

Fig. 4 presents the AFM phase images showing the effect of the incorporation of various weight ratios of the P3HT- $b$-PS copolymer on the morphology of thermally annealed P3HT:PCBM (1:1 w/w) films. The best morphology with interpenetrating nanoscale P3HT and PCBM domains has been achieved with $1 \mathrm{wt} \%$ P3HT- $b$-PS diblock copolymer, which correspond to the positive effect on phase separation with the largest surface area. Further increases in the concentration of P3HT- $b$-PS copolymer beyond $1 \mathrm{wt} \%$ resulted in large sphere like aggregates on the surface resembling P3HT- $b$-PS micelles. The strong interaction between PS block and PCBM molecules could make PCBM accumulate within PS block, ${ }^{36,37}$ causing a large aggregation of PCBM clusters. ${ }^{35}$

The TEM images of the P3HT:PCBM films containing various weight ratios of P3HT$b$-PS are presented in Fig. 5. These micrographs show that the addition of $1 \%$ P3HT- $b$-PS copolymer in P3HT:PCBM induces extensive crystallization and the formation of interconnected P3HT fibrils. In addition, this enhancement of crystallization of P3HT after annealing at $165{ }^{\circ} \mathrm{C}$ for 10 min leads to increased absorption and hole mobilities. This tendency was confirmed by Sun et al. and Yang et al. ${ }^{36,38}$

To summarize, the AFM and TEM images suggest that the addition of $1 \mathrm{wt} \%$ P3HT- $b$ PS copolymer can control the phase separation between P3HT and PCBM and obtain a more homogeneous film at a microscopic level. Fewer PCBM aggregates are formed when a small weight fraction of the copolymer is added as well as fewer extended P3HT fibrils. These 
results correlate well with each other and underline the cross-correlation between the agglomeration of PCBM and the formation of P3HT crystallites.

Fig. 6 shows the assembly of four AFM phase images of P3HT:PCBM (1:1 w/w) films annealed at $165{ }^{\circ} \mathrm{C}$ for 10 minutes with various weight ratios of the P3HT- $b$-PS-C 60 block copolymer. The best apparent morphology of interpenetrating nanoscale P3HT and PCBM domains was achieved at $0.5 \mathrm{wt} \%$ P3HT- $b$-PS- $b-\mathrm{C}_{60}$ block copolymer, corresponding to the highest interfacial areas. Furthermore, when increasing the ratio of additives (up to 5 $\mathrm{wt} \%$ ) one could observe that the crystalline structure was disrupted by the presence of large aggregates. Bulk morphologies were further investigated using bright field (BF) TEM images of thin films with various ratios of additives (Fig. 7 shows the P3HT:PCBM films with 0, 1, 1.5 and $5 \mathrm{wt} \%$ P3HT- $b$-PS-C 60 after annealing at $165{ }^{\circ} \mathrm{C}, 10 \mathrm{~min}$ ). When the amount of additive was progressively increased, the nanofibrillar morphology became clear and more defined. The addition of $0.5 \mathrm{wt} \%$ P3HT- $b$-PS-C 60 copolymer enhanced the crystallinity of the P3HT-chains in the blend and this enhancement is thought to be responsible of the increased charge transport and reduced bimolecular recombination that is detailed in the following section. $^{20,73}$

\section{Photovoltaic Characterizations}

We characterised the effect of different amounts of P3HT- $b$-PS copolymer in P3HT:PCBM $(1: 1)$ blends on the performance of photovoltaic devices. The obtained characteristics are reported in Fig. 6 and Table 2 where the variations of open circuit voltage $\left(V_{\mathrm{oc}}\right)$, short circuit current density $\left(J_{\mathrm{sc}}\right)$, fill factor $(F F)$ and PCE are observed as the proportion of P3HT-b-PS increases. Representative current density $(J)$-voltage $(V)$ curves are presented Figure 8(a), and they correspond to the data acquired for the $0,1,1.5$, and $5 \mathrm{wt} \%$ copolymer "doped" solar cells.

When the cells are not annealed there is a general, if slightly erratic, decrease in cell characteristics as the proportion of P3HT-b-PS increases. However, after thermal treatment, the performance of the devices was found to depend significantly on the amount of P3HT- $b$ PS copolymer. Without P3HT- $b$-PS, a PCE of $2.9 \%$ was obtained, but with the addition of 0.5 wt $\%$ P3HT- $b$-PS, the efficiency increased to $3.1 \%$. The best performance was achieved when $1 \mathrm{wt} \%$ P3HT- $b$-PS copolymer was added, i.e. $V_{\mathrm{OC}}=0.54 \mathrm{~V}, J_{\mathrm{SC}}=11 \mathrm{~mA} / \mathrm{cm}^{2}, \mathrm{FF}=0.61$, and PCE of $3.7 \%$. Nevertheless, a further increase in the proportion of P3HT- $b$-PS decreases efficiency. The FF and $J_{\mathrm{sc}}$ showed sensitivity to variations in the additives concentration (mainly $1 \mathrm{wt} \%$ ), whereas $V_{\mathrm{oc}}$ remained stable at around $0.55 \mathrm{~V}$, as shown in Table 2 . It is 
well known that $J_{S C}$ is strongly dependent on the absorption intensity shown in Fig. 3b, which is derived from the crystallinity of P3HT-chains, and the charge transport properties of networks in photovoltaic blend films. ${ }^{69-74}$ It is therefore apparent that it is the improvement in current with the morphological changes detailed in the prior section that drives the improved device characteristics. It should be noted, however that many other factors, such as blend ratio, regio-regularity, molar mass, annealing conditions, and additives can strongly affect the orientation of the P3HT chains, the size of PCBM domains and the overall morphology of the thin film.

When increasing the ratio ( $5 \mathrm{wt} \%$ ) of the copolymer additive in the P3HT:PCBM blend the device performance was found to decrease, most likely due to the disruption of P3HT crystallization resulting in a decrease in the population of the face-on oriented P3HT chains. ${ }^{35}$ Also, the strong interaction between the PS block and PCBM molecules could make PCBM accumulate within PS block, causing a large aggregation of PCBM clusters. ${ }^{36-37}$ Furthermore, the presence of insulating PS groups might hinder charge separation and transport.

Turning to P3HT- $b$-PS-C60, we see that the addition of $\mathrm{C}_{60}$ in the P3HT- $b$-PS chains permits a slight reduction in the use of additives to obtain even more enhanced results. Current-voltage $(J-V)$ curves under illumination were measured for five photovoltaic devices fabricated from blend films as cast and annealed with different loading ratios of P3HT- $b$-PS$\mathrm{C}_{60}$ diblock copolymer $(0,0.5,1.5,5 \mathrm{wt} \%)$. These results are shown in Fig. 9(a, b), from which the short-circuit current density $\left(J_{\mathrm{sc}}\right)$, the $V_{\mathrm{oc}}$, the fill factor $(F F)$, and the power conversion efficiency (PCE) are tabulated in Table 3. Again, without annealing the results are not particularly clear, which confirms that the effect is morphologically based: organisation of the devices is required for the effect to be observed. It is interesting to note though that a general descent in values with increasing concentration of additive is not seen, which would tend to indicate that these materials do not contain pernicious impurities that would otherwise act as charge-traps. The performance of the annealed photovoltaic cells was, however, found to depend significantly on the amount of P3HT- $b$-PS-C60 copolymer dopant. The power conversion efficiency of P3HT:PCBM blends without additives (after thermal annealing) was $3.01 \%$. After adding $0.5 \mathrm{wt} \%$ of the copolymer, the efficiency increased by more than $35 \%$ mainly due to a higher fill factor. $V_{\mathrm{oc}}=0.55 \mathrm{~V}, J_{\mathrm{sc}}=12.01 \mathrm{~mA} / \mathrm{cm}^{2}, \mathrm{FF}=0.61$, and PCE of $4.01 \%$ were achieved. As in the previous PV study, we note the independence of $V_{\mathrm{oc}}$ as the block copolymer additive concentration is varied. 
The incident photon to current efficiency (IPCE) curve showing the effectiveness of the cells at varying wavelengths and amounts of copolymers is given in Fig. 10. The highest IPCE was obtained with $0.5 \mathrm{wt} \%$ P3HT- $b$-PS- $b$-C60 additive with a maximum IPCE of $70 \%$, which is $5 \%$ greater than the maximum IPCE max of the P3HT:PCBM blend formulated with $1 \mathrm{wt} \%$ P3HT- $b$-PS. Both devices exhibited higher IPCEs than the standard P3HT:PCBM devices, correlating well with the JV data. The enhancements of the IPCEs on addition of the copolymers are explained by the increasing interfacial area between donor-acceptor domains leading to increased exciton dissociations and enhancement of charge carrier mobilities. The decreasing IPCEs with overly high amounts of copolymers (e.g. $5 \mathrm{wt} \%$ ) is responsible for an increased recombination rate due to large aggregates and a diminished crystalline structure.

\section{Stability Studies}

The active layer of the organic solar cell is prone to degradation (mainly thermal- and/or photo-oxidation phenomena) and has a direct effect on the loss in both the power conversion efficiency and device lifetime. In addition, the interfacial layer of P3HT:PCBM/Al is vulnerable towards molecular oxygen and water. The primary mechanisms of photo-oxidative degradation are well understood. ${ }^{74,75}$ Due to the sensitivity of the interface of nonencapsulated normal architecture devices (ITO/PEDOT/Active Layer/Al) towards molecular oxygen and water, we studied the stability of our devices in a glovebox under nitrogen. After plotting all curves of the reference and formulated devices in Figs 11 and 12, we demonstrate several interesting trends.

Figure 11 shows studies of the P3HT:PCBM + wt\% P3HT- $b$-PS devices under 1 sun $\left(\mathrm{AM} 1.5,50{ }^{\circ} \mathrm{C}\right)$ with normalized values measured under illumination $\left(100 \mathrm{~mW} \mathrm{~cm}{ }^{-2}\right)$. In the immediate time following illumination, the performance of devices $(0 \mathrm{wt} \%$ to $5 \mathrm{wt} \%$ of P3HT$b$-PS) started to decrease slowly. The device with $1 \%$ wt P3HT- $b$-PS showed the slowest decrease in efficiency with only a $10 \%$ loss, whereas the device with $5 \%$ wt P3HT- $b$-PS decreased by around 40\%. However, after $100 \mathrm{~h}$ illumination, the best devices (with $1 \mathrm{wt} \%$ P3HT- $b$-PS) started to degrade more rapidly than the reference device which may be attributed to one or more degradation mechanisms taking place.

A different story appears for P3HT- $b$-PS-C60 as indicated in Fig. 12. After the initial burn-in of the device, we find a near flat-line stability for this material over a long period of time when using the $0.5 \mathrm{wt} \%$ copolymer additive. The improvement over the reference devices is derived from the $\mathrm{C}_{60}$ moiety in the additive P3HT- $b$-PS-C60 which allows for increased donor-acceptor interfaces and reduction of isolated domains created by the 
polystyrene. Clearly, the addition of small amounts of P3HT- $b$-PS-C60 in P3HT:PCBM active layers improves the crystallization and stability.

So to sum, the addition of small amounts of $1 \mathrm{wt} \%$ P3HT- $b$-PS and $0.5 \mathrm{wt} \%$ P3HT- $b$ PS- $\mathrm{C}_{60}$ in the $\mathrm{P} 3 \mathrm{HT}: \mathrm{PC}_{60} \mathrm{BM}$ BHJs results to an increase in the $J_{\mathrm{SC}}$ allowing a best efficiency of $3.7 \%$ and $4 \%$ respectively, which is greater than the reference cell PCE of approximately $3 \%$ (while the $V_{\mathrm{OC}}$ and $F F$ are similar for all three devices). This can be seen more clearly in the log-log representation of the photocurrent as a function of effective applied voltage, $V_{\text {eff }}=$ $V_{0}-V$ curves, where higher dark injection currents are observed for devices containing additives compared to the neat binary blends. Fig. 13 shows the experimental photocurrent $J_{\mathrm{ph}}$ as a function of effective applied voltage $\left(V_{\text {eff }}=V_{0}-V\right)$ for P3HT:PCBM containing $0 \%, 1 \mathrm{wt} \%$ P3HT- $b$-PS, and $0.5 \mathrm{wt} \%$ P3HT- $b$-PS- $b$-C 60 after $1 \mathrm{~h}$ and $1000 \mathrm{~h}$ of lifetime. The photocurrent $\left(J_{\mathrm{ph}}=J_{\mathrm{L}}-J_{\mathrm{D}}\right)$ is the measured current under illumination $\left(J_{\mathrm{L}}\right)$ corrected for the dark current $\left(J_{\mathrm{D}}\right)$, whereas the compensation voltage $V_{0}$ is defined as the voltage at which the photocurrent $J_{\mathrm{ph}}$ is 0 . At voltages close to the compensation voltage $\left(V_{0}-V<0.1 \mathrm{~V}\right)$, the photocurrent is observed to increase linearly with voltage. For $V_{0}-V>0.1 \mathrm{~V}$, the photocurrent enters a regime where a square root dependence on the effective voltage is observed. Similar behaviour has been characterized in multiple conjugated polymer fullerene BHJ OPVs, where the decrease in photocurrent for $V_{0-} V>0.1 \mathrm{~V}$ is attributed to recombination effects. ${ }^{76-78}$ Specifically, the low mobilities or short lifetimes of free carriers (due to either recombination or trapping) are believed to limit the observed photocurrent in polymer solar cells. As seen in Fig. 13, after $1 \mathrm{~h}$ under illumination, polymer additives $1 \mathrm{wt} \%$ P3HT- $b$-PS (blue curves up triangle symbol) and $0.5 \mathrm{wt} \%$ P3HT- $b$-PS-C60 (magenta curves, square symbol) consistently yield higher photocurrents in the square root regime $\left(\mathrm{V}_{0}-\mathrm{V}>0.1 \mathrm{~V}\right)$ compared to $\mathrm{P} 3 \mathrm{HT}: \mathrm{PC}_{60} \mathrm{BM}$ reference cells (black curves, circle symbol), thus suggesting that these additives decrease charge recombination. This can be attributed to the nanostructuring of the P3HT:PCBM domain, leading to an increase of the interfacial area between the donor/acceptor phases as well as an improved hole transport.

After $1000 \mathrm{~h}$ under illumination in glovebox, Fig. 11 shows a decreased photocurrent of P3HT:PCBM $+1 \mathrm{wt} \%$ P3HT- $b$-PS over the binary reference cell. This increased charge recombination in the doped active layer is due to decreased mobility and disruption of the nanostructured morphology of the active layer. On the other hand, after $1000 \mathrm{~h}$ the PSC with a P3HT:PCBM $+0.5 \mathrm{wt} \%$ P3HT- $b$-PS-C60 active layer shows a higher stability over the reference cell. This is due to the $\mathrm{C}_{60}$ grafted on the polystyrene side (P3HT- $b$-PS- $\mathrm{C}_{60}$ ) of the additives which allows an increase in the donor/acceptor interface by reducing the insulating 
character of the additive and inducing a preferred active layer morphology. In conclusion, this study has shown that the P3HT- $b$-PS-C60 copolymer additive is a good approach for obtaining a solar cell with increased performance and stability.

\section{Conclusions}

We have discussed the effect of P3HT- $b$-PS- $b-\mathrm{C}_{60}$ and P3HT- $b$-PS diblock copolymers as additives in classical P3HT:PCBM bulk heterojunction solar cells which can serve to synergistically improve the power-conversion efficiency and lifetime of photovoltaic solar cells. At optimal concentrations, the block copolymer additives were found to induce favorable active layer morphologies with interpenetrating nanoscale domains, enhance P3HT crystallinity and facilitate holes transport within the active layer. The AFM and TEM characterization of the films provides evidence that the PS segments' affinity with PCBM is a major driving force to control phase separation in P3HT:PCBM blends. As well, the P3HT is inherently attracted to the P3HT block of the copolymer, which leads to improvements in long-range ordering. The results show that the addition of small amounts of the PS- $b$-P3HT and P3HT- $b$-PS- $b-\mathrm{C}_{60}$ dopant affects the PCBM domain size. Best performances were obtained with a P3HT- $b$-PS and P3HT- $b$-PS- $b-\mathrm{C}_{60}$ concentration of $1 \mathrm{wt} \%$ and $0.5 \mathrm{wt} \%$ respectively, which we attribute to an increase in miscibility of P3HT and PCBM driven by the copolymer additive. However, the $\mathrm{C}_{60}$ functionalization P3HT- $b$-PS- $b$ - $\mathrm{C}_{60}$ was by far the most effective way to control phase separation, crystallinity, and to improve donor/acceptor interfacial area within the P3HT:PCBM blends. This resulted in both an enhancement of the performance of the BHJ PSC and an increased lifetime by stabilizing the active layer morphology.

\section{Acknowledgements}

Dr. C. Abasalon, at the Center for Study and Structural Analysis of Organic Molecules (CESAMO), University of Bordeaux, is warmly thanked for MALDI-TOF characterisations. Dr. Mathieu Urien is sincerely thanked for his very useful advice and discussions. 


\section{References}

1 a) M. A. Green, K. Emery, Y. Hishikawa, W. Warta and E. D. Dunlop, Prog. Photovolt. Res. Appl. 2012, 20, 12; b) H. Spanggaard and F. C. Krebs, Solar Energy Materials \& Solar Cells, 2004, 83, 125; c) C. J. Brabec, N. S. Sariciftci and J. C. Hummelen, Adv. Funct. Mater. 2011, 11, 15; d) J. Nelson, Materials Today, 2011, 14, 462.

G. Li, V. Shrotriya, J. Huang, Y. Yao, T. Moriarty, K. Emery and Y. Yang, Nat. Mater. 2005, 4, 864.

3 G. Li, R. Zhu and Y. Yang, Nat. Photonics 2012, 6, 153.

4 S. Günes, H. Neugebauer and N. S. Sariciftci, Chem. Rev. 2007, 107, 1324.

5 B. C. Thompson, J. M. J. Frechet, Angew. Chem. Int. Ed. 2008, 47, 58.

6 a) S. H. Park, A. Roy, S. Beaupré, S. Cho, N. Coates, J. S. Mon, D. Moses, M. Leclerc, K. Lee and A. J. Heeger, Nat. Photon 2009, 3, 297; b) J. Y. Kim, K. Lee, N. E. Coates, D. Moses, T. Q. Nguyen, D. Dante and A. J. Heeger, Science 2007, 317, 222. c) S. B. Darling and F. You, RSC Adv. 2013, 3, 17633.

7 M. Jørgensen, K. Norrman, S. A. Gevorgyan, T. Tromholt, B. Andreasen and F. C. Krebs, Adv. Mater. 2011, 24, 580.

8 L.-M. Chen, Z. Xu, Z. Hong and Y. Yang, J. Mater. Chem. 2010, 20, 2575.

9 E. D. Gomez and Y.-L. Loo, J. Mater. Chem. 2010, 20, 6604.

10 H. Ma, H.-L. Yip, F. Huang and A. K. Y. Jen, Adv. Funct. Mater. 2010, 20, 1371.

11 M. T. Dang, L. Hirsch and G. Wantz, G. Adv. Mater. 2011, 23, 3597.

12 a) P.-L. T. Boudreault, A. Najari and M. Leclerc, Chem. Mater. 2011, 23, 456; b) M. He, M. Wang, C. Lin and Z. Lin, Nanoscale, 2014, 6, 3984; c) I. Botiz and N. Stingelin, Materials 2014, 7, 2273.

13 J. Peet, M. L. Senatore, A. J. Heeger and G. C. Bazan, Adv. Mater. 2009, 21, 1521.

14 D. Mark, J. Peet and T.-Q. Nguyen, J. Phys. Chem. C 2008, 112, 7241.

15 J. S. Moon, C. J. Takacs, S. Cho, R. C. Coffin, H. Kim, G. C. Bazan and A. J. Heeger, NanoLett. 2010, 10, 4005.

16 J. Peet, J. Y. Kim, N. E. Coates, W. L. Ma, D. Moses, A. J. Heeger and G. C. Bazan, Nat. Chem. 2007, 6, 497.

17 J. K. Lee, W. L. Ma, C. J. Brabec, J. Yuen, J. S. Moon, J. Y. Kim, K. Lee, G. C. Bazan and A. J. Heeger, J. Am. Chem. Soc. 2008, 130, 3619.

18 M. Urien, L. Bailly, L. Vignau, E. Cloutet, A. de Cuendias, G. Wantz, H. Cramail, L. Hirsh and J.-P. Parneix, Polym. Int. 2008, 57, 764.

19 K. Sivula, Z. T. Ball, N. Watanabe and J. M. J. Frechet, Adv. Mater. 2006, 18, 206.

20 J. U. Lee, J. W. Jung, T. Emrick, T. P. Russell, W. H. Jo, Nanotechnology, 2010, 21, 105201.

21 C. J. Hawker, M. L. Chabinyc, Adv. Energy Mater. 2011, 1, 82.

22 R. A. Segalman, B. McCulloch, S. Kirmayer and J. J. Urban, Macromolecules 2009, 42, 9205.

23 N. Sary, F. Richard, C. Brochon, N. Leclerc, P. Lévêque, J.-N. Audinot, S. Berson, T. Heiser, G. Hadziioannou and R. Mezzenga, Adv. Mater. 2010, 22, 763.

24 N. Sary, L. Rubatat, C. Brochon, G. Hadziioannou and R. Mezzenga, Macromol. Symp. 2008, 268, 28.

25 N. Sary, L. Rubatat, C. Brochon, G. Hadziioannou, J. Ruokolainen and R. Mezzenga, Macromolecules 2007, 40, 6990.

$26 \mathrm{Ph}$. Leclere, V. Parente, J. L. Bredas, B. Francois and R. Lazzaroni, Chem. Mater. 1998, 10, 4010.

27 M. Muthukumar, C. K. Ober and E. L. Thomas, Science 1997, 277, 1225.

28 S. A. Jenekhe and L. X. Chen, Science 1999, 283, 372.

29 M. He, F. Qiub and Z. Lin, J. Mater. Chem. 2011, 21, 17039.

30 P. D. Topham, A. J. Parnell and R. C. Hiorns, J. Polym. Sci. Pt B: Polym. Phys. 2011, 49, 1131.

31 A. de Cuendias, R. C. Hiorns, E. Cloutet, L. Vignau and H. Cramail, Polym. Int. 2010, 11, 1452.

32 M. Sommer, S. Huttner, U. Steiner and M. Thelakkat, Appl. Phys. Lett. 2009, 95, 183308.

33 N. Sary, F. Richard, C. Brochon, N. Leclerc, P. Leveque, J. N. Audinot, S. Berson, T. Heiser, G. Hadziioannou and R. Mezzenga, Adv. Mater. 2010, 22, 763.

34 M. Han, H. Kim, H. Seo, B. Ma and J. -W. Park, Adv. Mater. 2012, 24, 6311. 
C. Renaud, S.-J. Mougnier, E. Pavlopoulou, C. Brochon, G. Fleury, D. Deribew, G Portale, E. Cloutet, S. Chambon, L. Vignau and G. Hadziioannou, Adv. Mater. 2012, 24, 2196.

36 Z. Sun, K. Xiao, J. K. Keum, X. Yu, K. Hong, J Browning, I. N. Ivanov, J. Chen, J. Alonzo, D. Li, B. G. Sumpter, E. A. Payzant, C. M. Rouleau and D. B. Geohegan, Adv. Mater. 2011, 23, 5529.

37 a) D. Deribew, E. Pavlopoulou, G. Fleury, C. Nicolet, C. Renaud, S.-J. Mougnier, L. Vignau, E. Cloutet, C. Brochon, F. Cousin, G. Portale, M. Geoghegan and Hadziioannou, Macromolecules 2013, 46, 3015; b) S. B. Darling, Energy Environ. Sci. 2009, 2, 1266; c) I. Botiz and S. B.

Darling, Materials Today, 2010, 13, 42.

38 C. Yang, J. K. Lee, A. J. Heeger, F. Wudl, J. Mater. Chem. 2009, 19, 5416.

39 a) C. Wang, Z.-X. Guo, S. Fu, W. Wu and D. Zhu, Prog. Polym. Sci. 2004, 29, 1079; b) J. U. Lee, A. Cirpan, T. Emrick, R. P. Russell and W. H. Jo, J. Mater. Chem. 2009, 19, 1483; b) J. U. Lee, J. W. Jung, T. Emrick, T. P. Russell and W. H. Jo, J. Mater. Chem. 2010, 20, 3287; c) J. U. Lee, Y. D. Kim, J. W. Jo, J.-P. Kim and W. H. Jo, J. Mater. Chem. 2011, 21, 17209; d) D. A> Kamkar, M. Wang, F. Wudl and T.-Q. Nguyen, ACS Nano 2012, 6, 1149; e) X.-H. Dong, W.-B. Zhang, Y. Li, M. Huang, S. Zhang, R. P. Quirk and S. Z. D. Cheng, Polym. Chem. 2012, 3, 124. P. Zhou, G.-Q. Chen, C.-Z. Li, F.-S. Du, Z.-C. Li and F.-M. Li, Chem. Commun. 2000, 9, 1948.

P. Zhou, G.-Q. Chen, C.-Z. Li, F.-S. Du, Z.-C. Li and F.-M. Li, Macromolecules 2001, 33, 1948.

42 F. Audoin, S. Nunige, R. Nuffer and C. Mathis, Synthetic Metals 2001, 121, 1149.

43 a) F. Audoin, R. Nuffer and C. Mathis J. Polym. Sci.: Pt A: Polym. Chem. 2004, 42, 3456; b) C. Mathis, B. Schmaltz and M. Brinkmann C. R. Chimie 2006, 9, 1075.

44 J. S. Moon, J. K. Lee, S. Cho, J. Byun and A. J. Heeger, Nano Lett. 2008, 9, 230.

45 D. L. Handlin and E. L. Thomas, Macromolecules 1983, 16, 1514.

46 Y. Vaynzof, D. Kabra, L. Zhao, L. L. Chua, U. Steiner and R. H. Friend, ACS Nano 2011, 5, 329.

47 W. Ma, J. Y. Kim, K. Lee and A. J. Heeger, Macromol. Rapid Commun. 2007, 28, 1776.

48 J. S. Moon, C. J. Takacs, Y. Sun and A. J. Heeger, Nano Lett. 2011, 11, 1036.

49 F. C. Krebs, S.A. Gevorgyan and J. Alstrup, J. Mater. Chem., 2009, 19, 5442.

50 a) A. Yokoyama, R. Miyakoshi and T. Yokozawa, Macromolecules 2004, 37, 1169;

b) E. E. Sheina, J. Liu, M. C. Iovu, W. Darin, D. W. Laird and R. D. McCullough, Macromolecules, 2004, 37, 3526; c) M. Jeffries-El, G. Sauvé and R. D. McCullough, 2004, 16, 1017; d) R. C. Hiorns, A. Khoukh, B. Gourdet, C. Dargron-Lartigau, Polym. Int. 2006, 55, 608.

M. Jeffries-El, G. Sauvé, R. D. McCullough, Macromolecules 2005, 38, 10346.

52 M. Urien, H. Erothu, E. Cloutet, R. C. Hiorns, L. Vignau and H. Cramail, Macromolecules 2008, 41, 7033.

53 J. Liu, R. S. Loewe and R. D. McCullough, Macromolecules 1999, 32, 5777.

54 D. Quémener, T. P. Davis, C. Barner-Kowollik and M. H. Stenzel, Chem. Comm. 2006, 5051

55 V. Fernandez-Santana, R. Gonzalez-Lio, J. Sarracent-Perez, V. Verez-Bencomo, Glycoconjugate Journal 1998, 15, 549.

56 F. A. Carey and R. J. Sundberg, Chimie Organique Avancée Tome 2: Réactions et Synthèses, Ed. De Boeck Université, 1997.

57 J. Xia, X. Zhang and K. Matyjaszewski, K. ACS Symp. Ser. 2000, 760, 207.

58 W. H. Binder and R. Sachenhofer, Macromol. Rapid Commun. 2008, $29,952$.

59 a) H. C. Kolb, M. G. Finn and K. B. Sharpless, Angew. Chem., Int. Ed. 2001, 40, 2004;

b) J. A. Opsteen and J. C. M. Van Hest, Chem. Commun. 2005, 57; c) D. Quémener, T. P. Davis, C. Barner-Kowollik and M. H. Stenzel, Chem. Commun. 2006, 5051; d) W. Agut, D. Taton and S. Lecommandoux, Macromolecules 2007, 40, 5653; e) W. H. Binder and R. Sachsenhofer, Macromol. Rapid Commun. 2007, 28, 15.

60 T. L. Benanti, A. Kalaydjian and D. Venkataraman, Macromolecules 2008, 41, 8312.

61 Y. Tao, B. Mcculloch, S. Kim and R. A. Segalman, Soft Matter 2009, 5, 4219.

62 A. Jatsch, A. Kopyshev, E. Mena-Osteritz, P. Bauerle, Organic Letters, 2008, 10, 961.

63 R. Miyakoshi, A. Yokoyama and T. Yokozawa, Macromol. Rapid Commun. 2004, 25, 1663.

64 G. Zhou, Q. Chen, F. S. Du, Z. C. Li and F. M. Li, Acta Polym. Sin. 1999, 6, 757. 
65 R. C. Hiorns, R. de Bettignies, J. Leroy, S. Bailly, M. Firon, C. Sentein, A. Khoukh, H. Preud'homme, C. Dagron-Lartigau, Adv. Funct. Mater. 2006, 16, 2263.

66 a) S. Miki, M. Kitao and K.; Fukunishi, Tetrahedron Lett. 1996, 37, 2049;

b) R. C. Hiorns, E. Cloutet, E. Ibarboure, A. Khoukh, H. Bejbouji, L. Vignau and H. Cramail, Macromolecules 2010, 43, 6033; c) W. Chen, M. P. Nikiforov and S. B. Darling, Energy Environ. Sci., 2012, 5, 8045.

67 W. C. Tsoi, S. J. Spencer, L. Yang, A. M. Ballantyne, P. G. Nicholson, A. Turnbull, A. G. Shard, C. E. Murphy, D. D. C. Bradley, J. Nelson and J.-S. Kim, Macromolecules 2011, 44, 2944.

68 F. C. Krebs, T. D. Nielsen, J. Fyenbo, M. Wadsrøm and M. S. Pedersen, Energy Environ. Sci. $2010,3,512$.

69 M. C. Scharber, D. Muhlbacher, M. Koppe, P. Denk, C. Waldauf and A. J. Heeger, Adv. Mater. 2006, 18, 789.

70 A. Orimo, K. Masuda, S. Honda, H. Benten, S. Ito, H. Ohkita and H. Tsuji, Appl. Phys. Lett. 2010, 96, 043305.

71 V. Shrotriya, J. Ouyang, R. J. Tseng, R. G. Li and R. Y. Yang, Chem. Phys. Lett. 2005, 411, 138.

72 Y. Zhao, Z. Xie, Y. Qu, Y. Geng, L. Wang, Appl. Phys. Lett. 2007, 90, 043504.

73 F. Liu, Y. Gu, J. W. Jung, W. H. Jo, T. P. Russell J. Polym. Sci.: Pt B: Polym. Phys. 2012, 50, 1018.

74 a) H. Hintz, H. Peisert, H.-J. Egelhaaf and T. Chassé, J. Phys. Chem. C, 2011, 115, 13373; b) A. Dupuis, P. Wong-Wah-Chung, A. Rivaton and J.-L. Gardette, Polym. Degrad. Stab., 2012, 97, 366; c) A. Rivaton, A. Tournebize, J. Gaume, P.-Q. Bussière, J.-L. Gardette and S. Therias, Polym. Int. 2013, 63, 1335; d) M. Hermenau, M. Riede, K. Leo, S. A. Gevorgyan, F. C. Krebs and K. Norrman, Sol. Energy Mater. Sol. Cells 2011, 95, 1268; e) H. Santos Silva, A. Tournebize, D. Bégué, H. Peisert, T. Chassé, J.-L. Gardette, S. Therias, A. Rivaton and R. C. Hiorns, RSC Adv. 2014, 4, 54919.

75 a) K. Norrman, N. B. Larsen and F. C. Krebs, Solar Energy Materials \& Solar Cells, 2006, 90, 2793; b) M. P. Nikiforov, J. Strzalka, S. B. Darling, Solar Energy Materials \& Solar Cells, 2013, 110, 36; c) E. F. Palermo, S. B. Darling and A. J. McNeil, J. Mater. Chem. C, 2014, 2, 3401.

76 J. M. Lobez, A. L. Andrew, V. Bulovi and T. M. Swager, ACS Nano 2012, 6, 3044.

77 M. Lenes, M. Morana, C. J. Brabec and P. W. M. Blom, Adv. Funct. Mater. 2009, 19, 1106.

78 V. D. Mihailetchi, L. J. A. Koster, P. W. M. Blom, C. Melzer, B. de Boer, J. K. J. van Duren and R. A. J. Janssen, Adv. Funct. Mater. 2005, 15, 795. 


\section{Scheme}

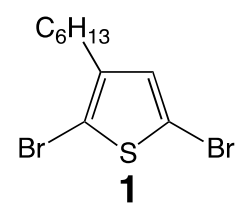

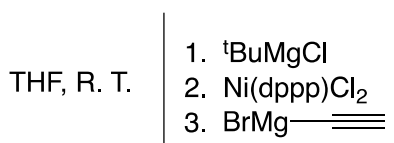

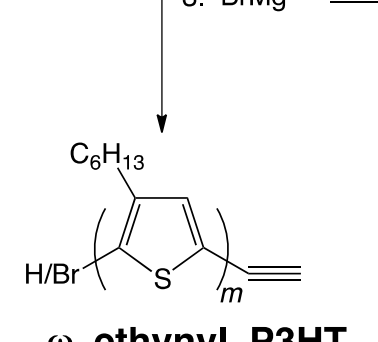<smiles>CC(C)(Br)C(=O)OCCCN</smiles>

2<smiles>CC(C)(C)C(=O)OCCCN</smiles>

$\alpha$-azido- $\omega$-bromo-PS

$$
\text { THF, } 50^{\circ} \mathrm{C} \text {, }
$$

Cul, $\left(\mathrm{C}_{2} \mathrm{H}_{5}\right)_{2} \mathrm{NH}$,

sonification<smiles>Cc1cc(C(C)(C)C)sc1C(C)C</smiles>

P3HT-b-PS

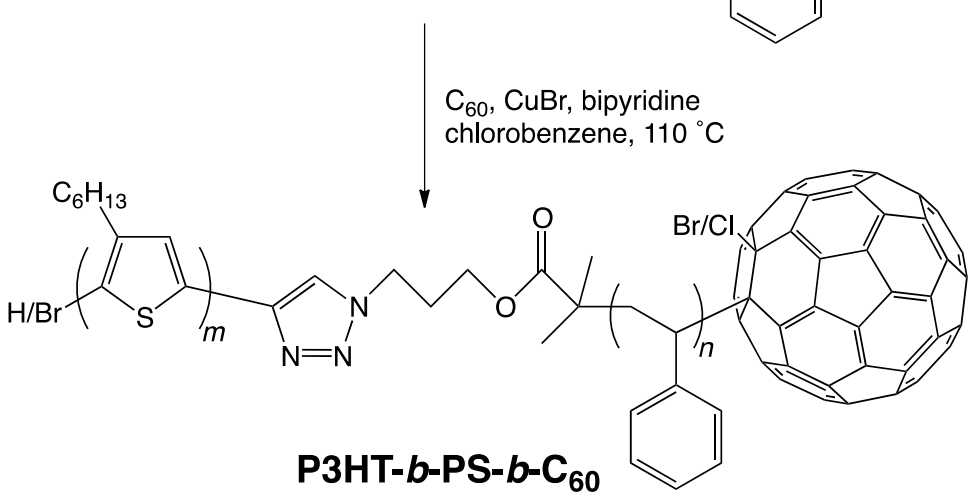

Scheme 1. Route to block copolymers.

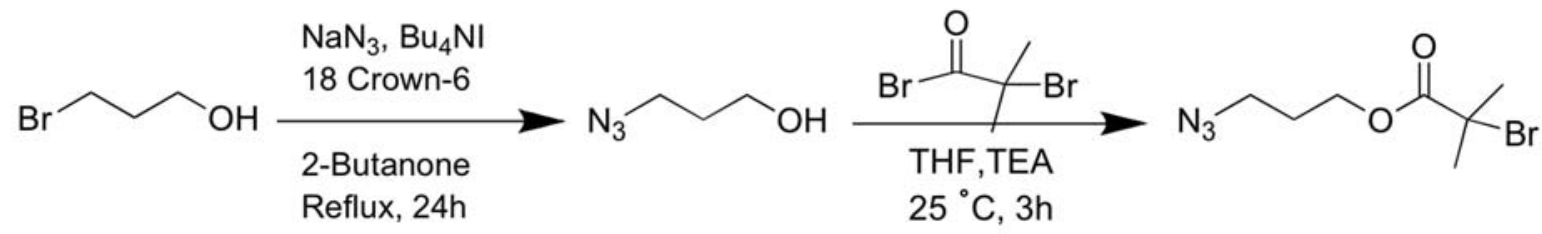

Scheme 2. Preparation of the ATRP initiator. 

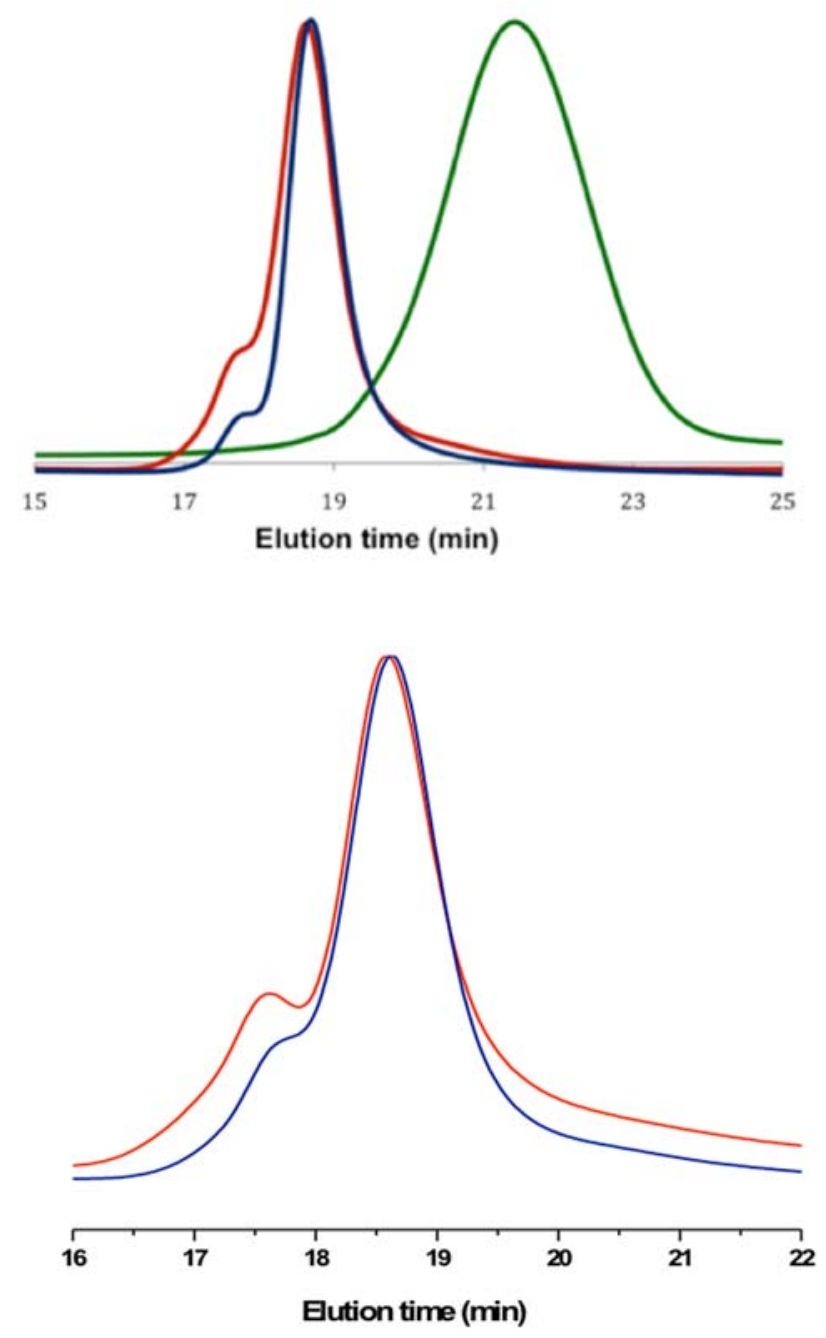

Figure 1. Normalised SECs (THF, UV-254 nm) of: (top) $\alpha$-azido- $\omega$-bromo-PS (green), $\omega$ ethynyl-P3HT (blue), and P3HT- $b$-PS (red); and (below) of P3HT- $b$-PS (blue) and P3HT- $b-$ PS-C60 (red). 


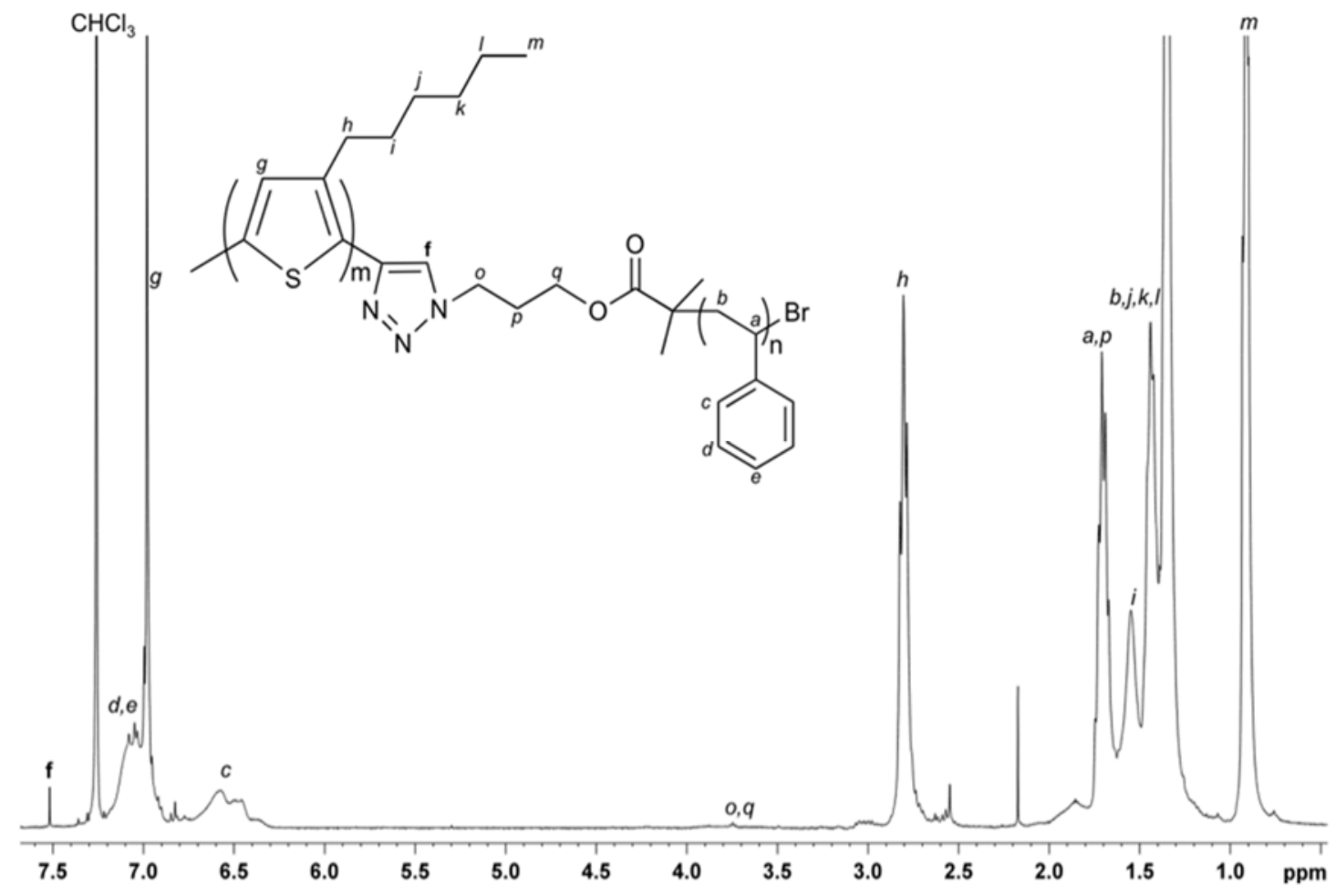

Figure 2. ${ }^{1} \mathrm{H} \mathrm{NMR}\left(400 \mathrm{MHz}, \mathrm{CDCl}_{3}\right)$ spectrum of P3HT- $b$-PS. 


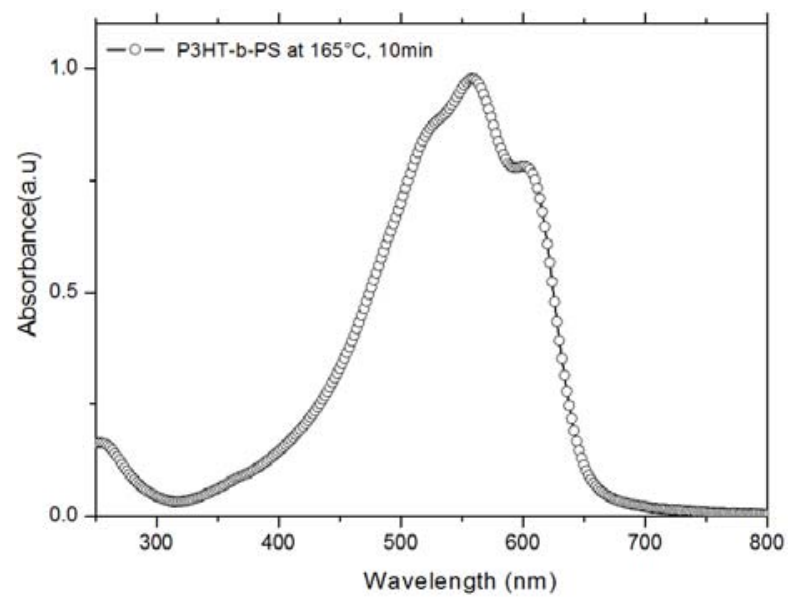

(a)

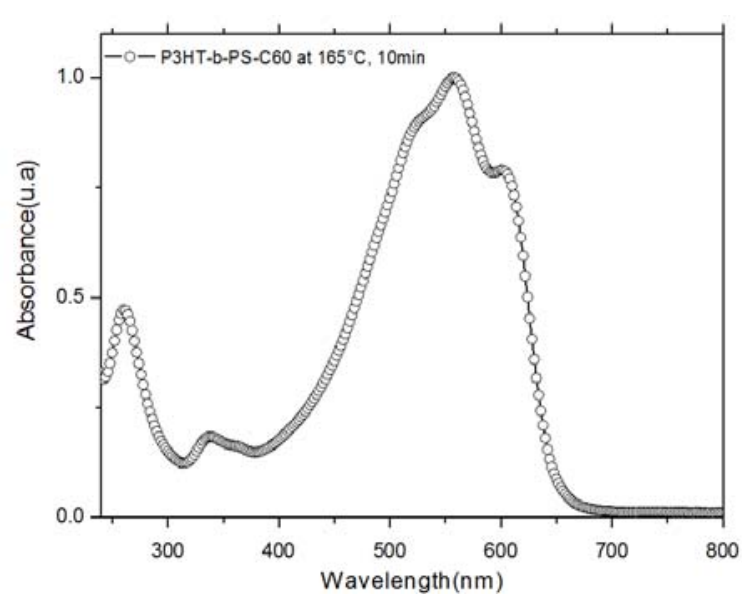

(c)

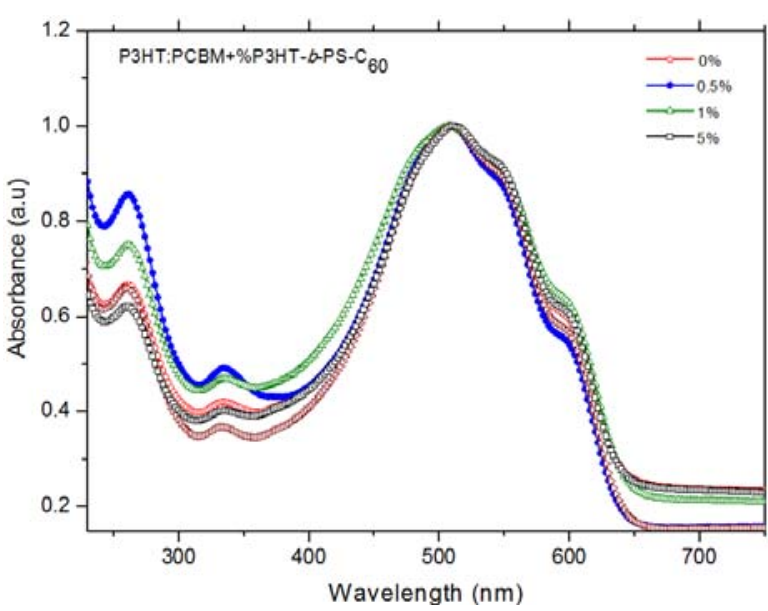

(d)

Figure 3. UV-visible spectra of: (a) P3HT- $b$-PS; (b) P3HT:PCBM blend with varying wt $\%$ loads of P3HT- $b$-PS; (c) P3HT- $b$-PS-C 60 ; and (d) P3HT:PCBM with varying wt $\%$ loads of P3HT- $b$-PS- $b-\mathrm{C}_{60}$ (all annealed at $165^{\circ} \mathrm{C}, 10 \mathrm{~min}$ ). 

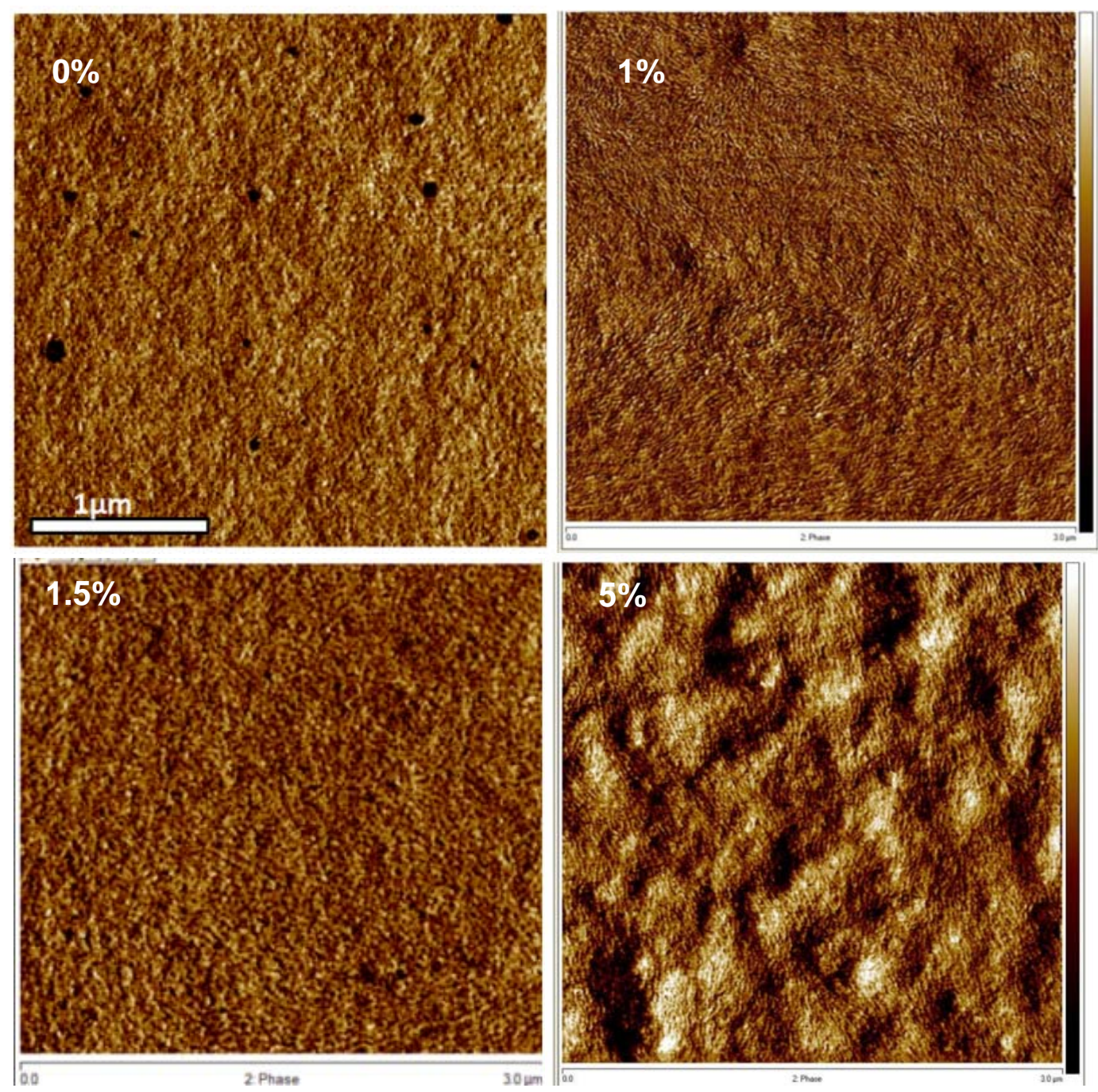

Figure 4. AFM phase images of P3HT:PCBM blends mixed with varying $w t \%$ loads of P3HT- $b$-PS, (all $3 \times 3 \mu \mathrm{m}$ tapping mode of samples annealed at $165^{\circ} \mathrm{C}, 10 \mathrm{~min}$ ). 

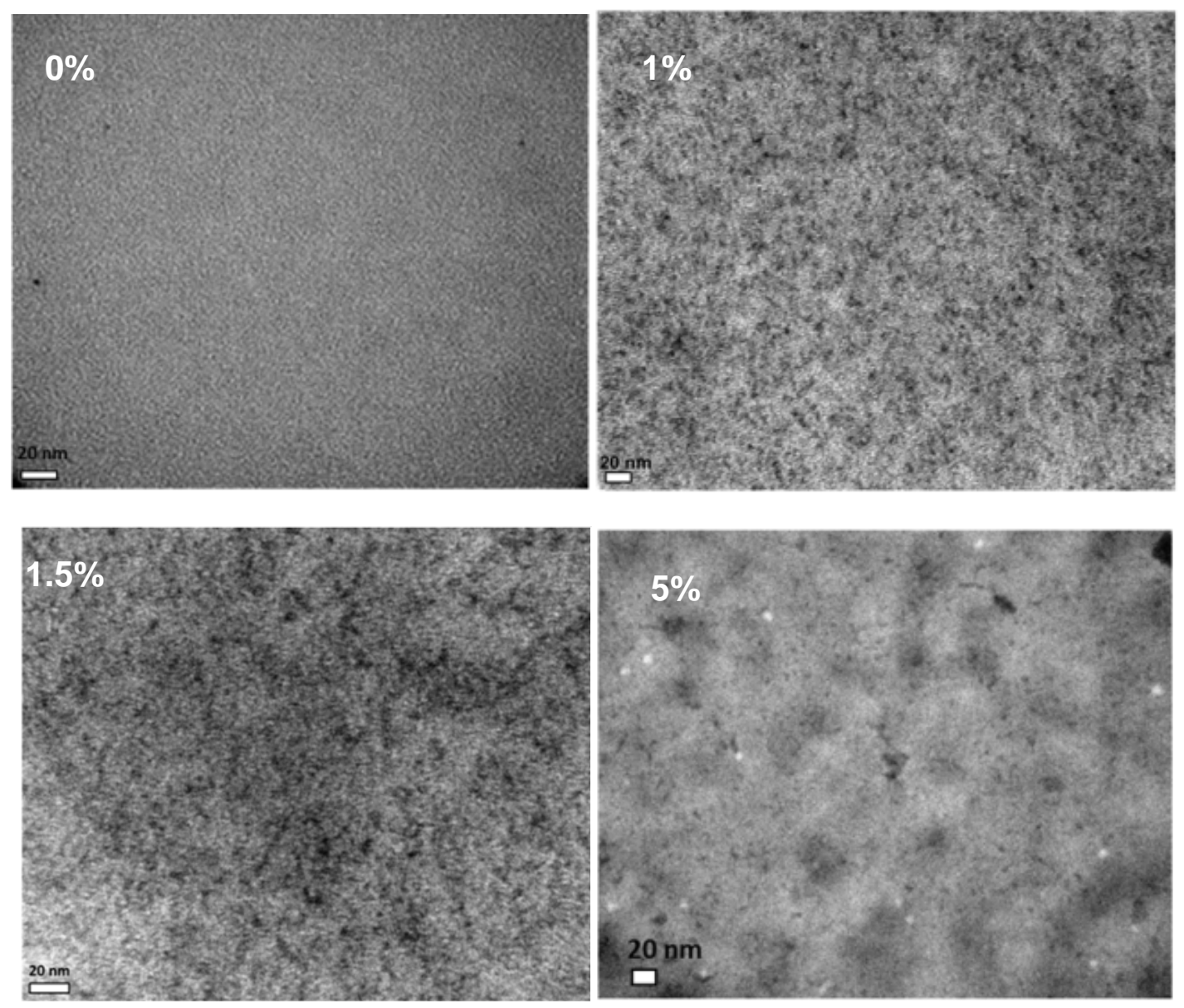

Fig. 5. BF TEM images of P3HT:PCBM with $0,1,1.5$ and $5 \mathrm{wt} \%$ P3HT- $b$-PS loads (all samples annealed at $165^{\circ} \mathrm{C}, 10 \mathrm{~min}$ ). 

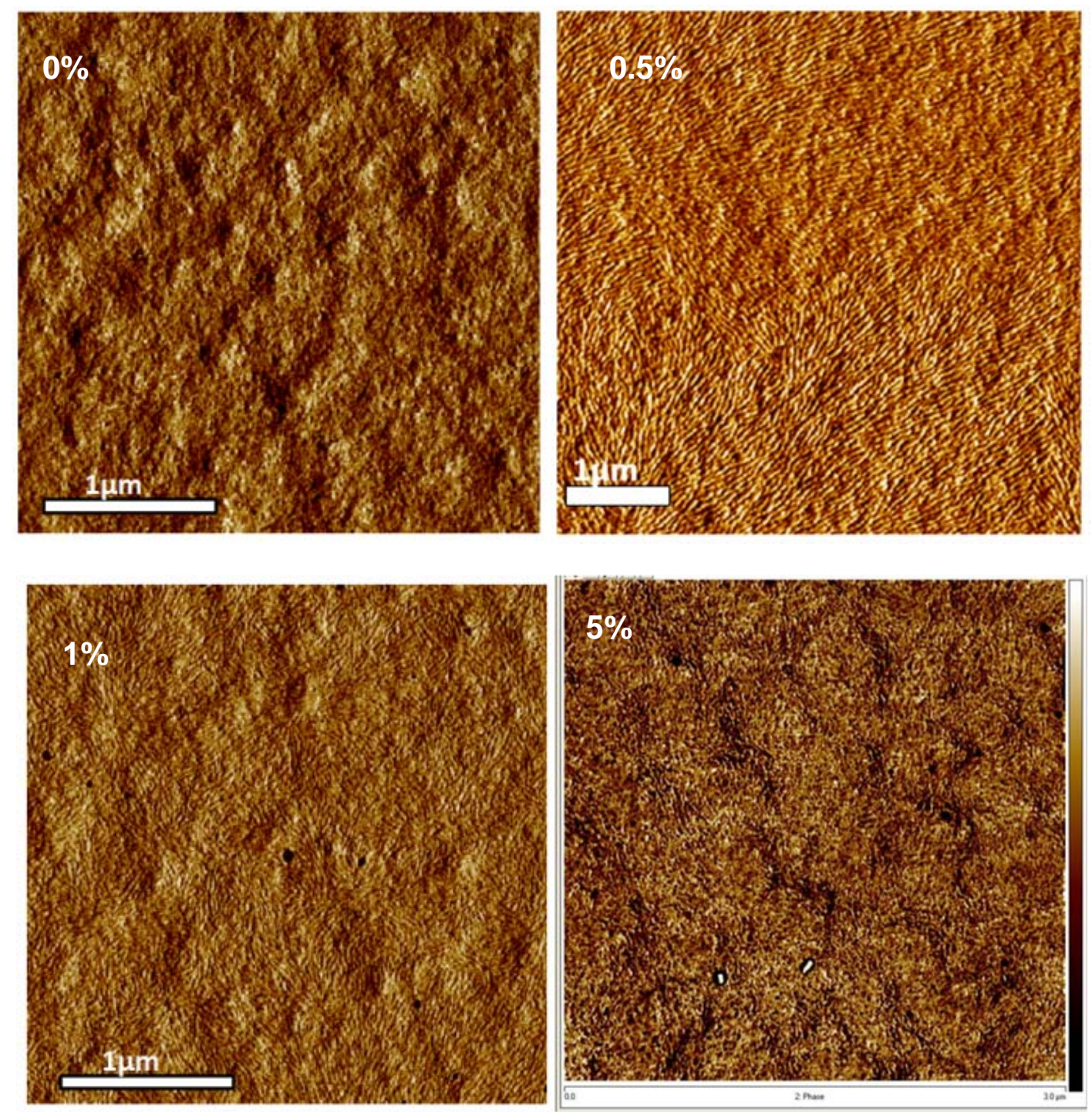

Figure 6. AFM images of P3HT:PCBM blends mixed with varying wt $\%$ loads of P3HT- $b$ PS- $\mathrm{C}_{60}$, (all $3 \times 3 \mu \mathrm{m}$ tapping mode of samples annealed at $165^{\circ} \mathrm{C}, 10 \mathrm{~min}$ ). 

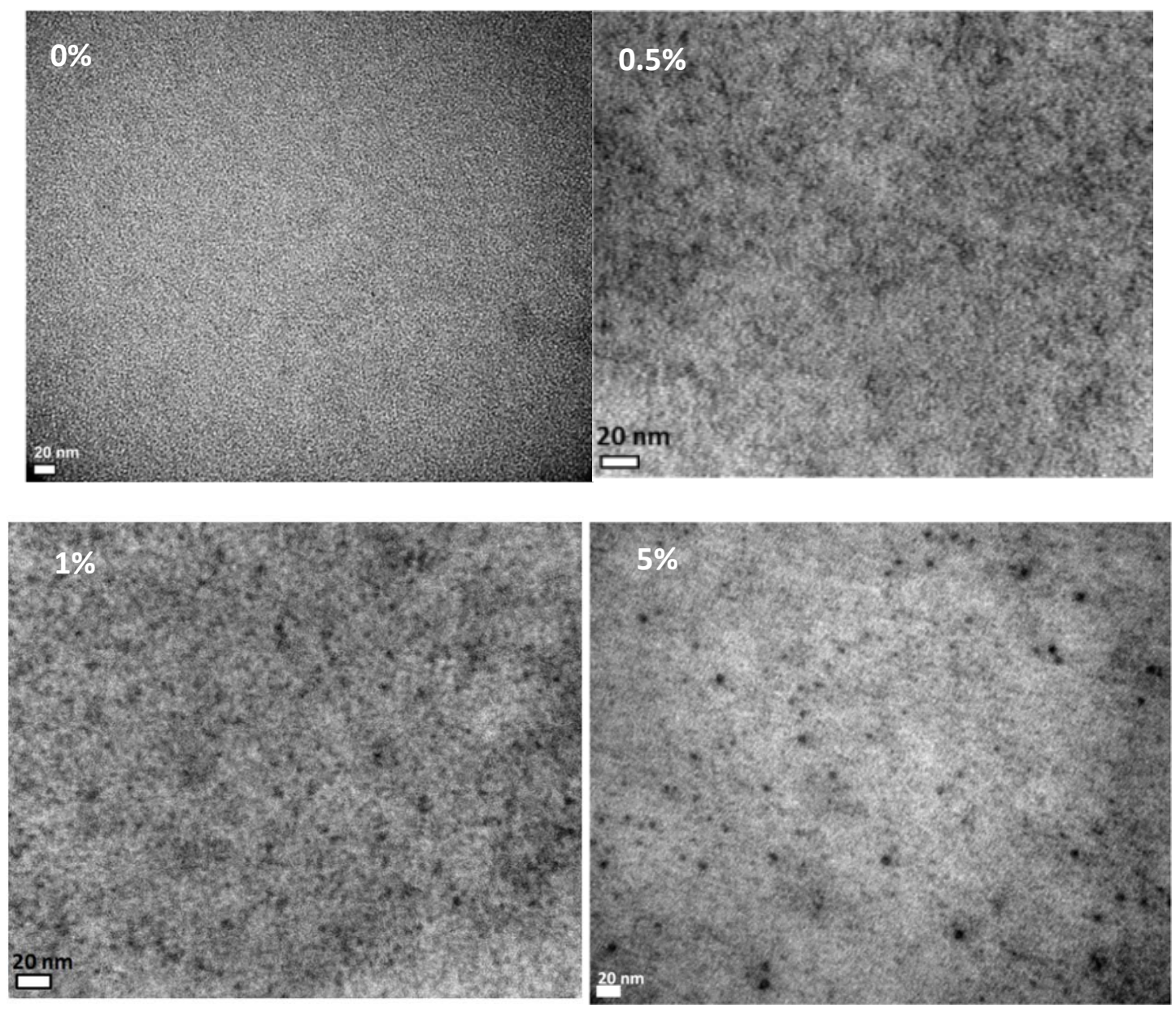

Figure 7. BF TEM images of P3HT:PCBM with $0,1,1.5$ and $5 \% \mathrm{w} / \mathrm{w}$ P3HT- $b$-PS-C 60 loads (all samples annealed at $165^{\circ} \mathrm{C}, 10 \mathrm{~min}$ ). 

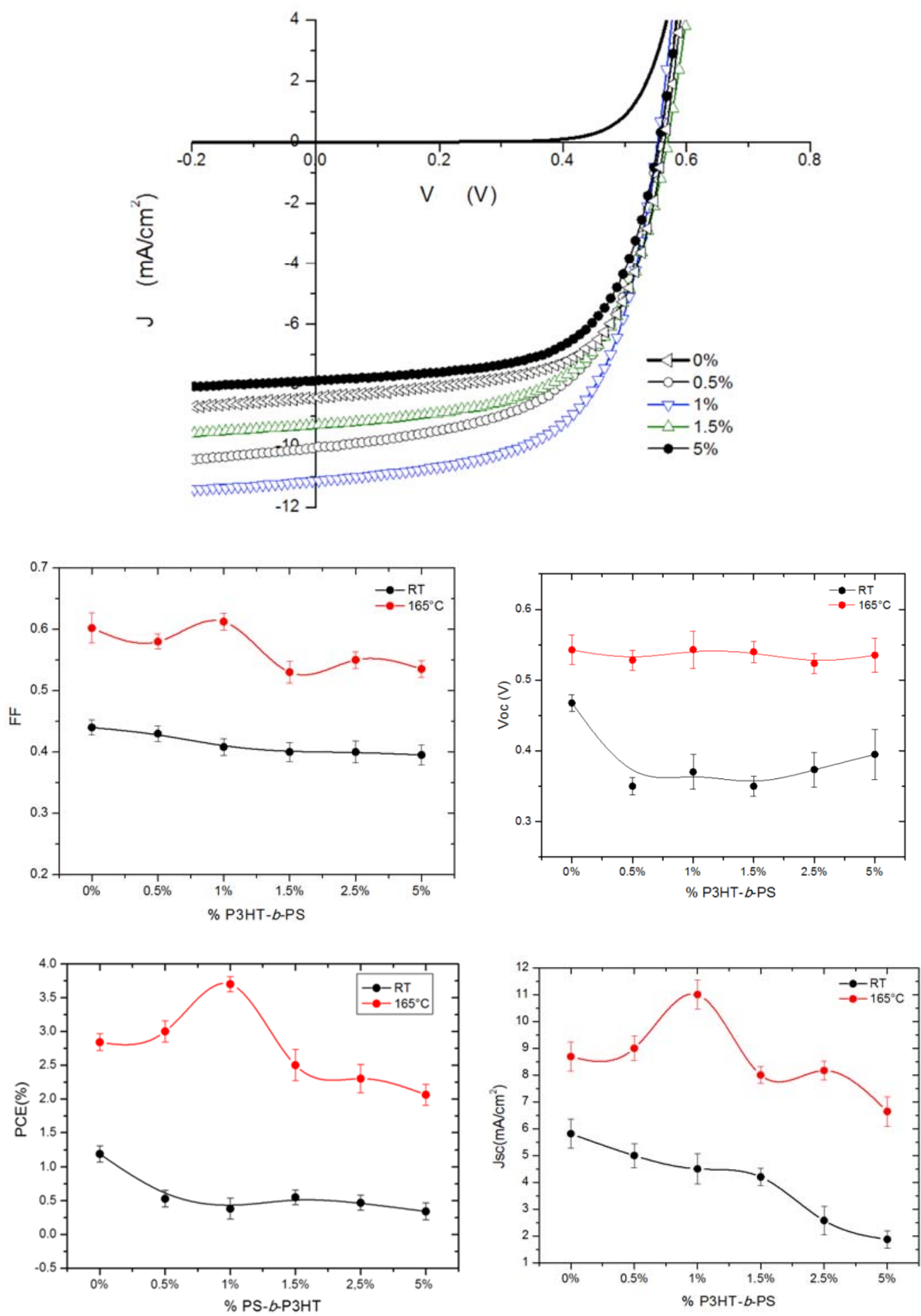

Figure 8: Photovoltaic characteristics of P3HT:PCBM blended with various \%wt of P3HT- $b$ PS: (top) J-V characteristics; (below) $F F, V_{\mathrm{oc}}, J_{\mathrm{sc}}$, and PCE (\%), obtained with as-cast (black) and annealed (red) solar cells. Error bars were calculated from an average over 16 devices. 

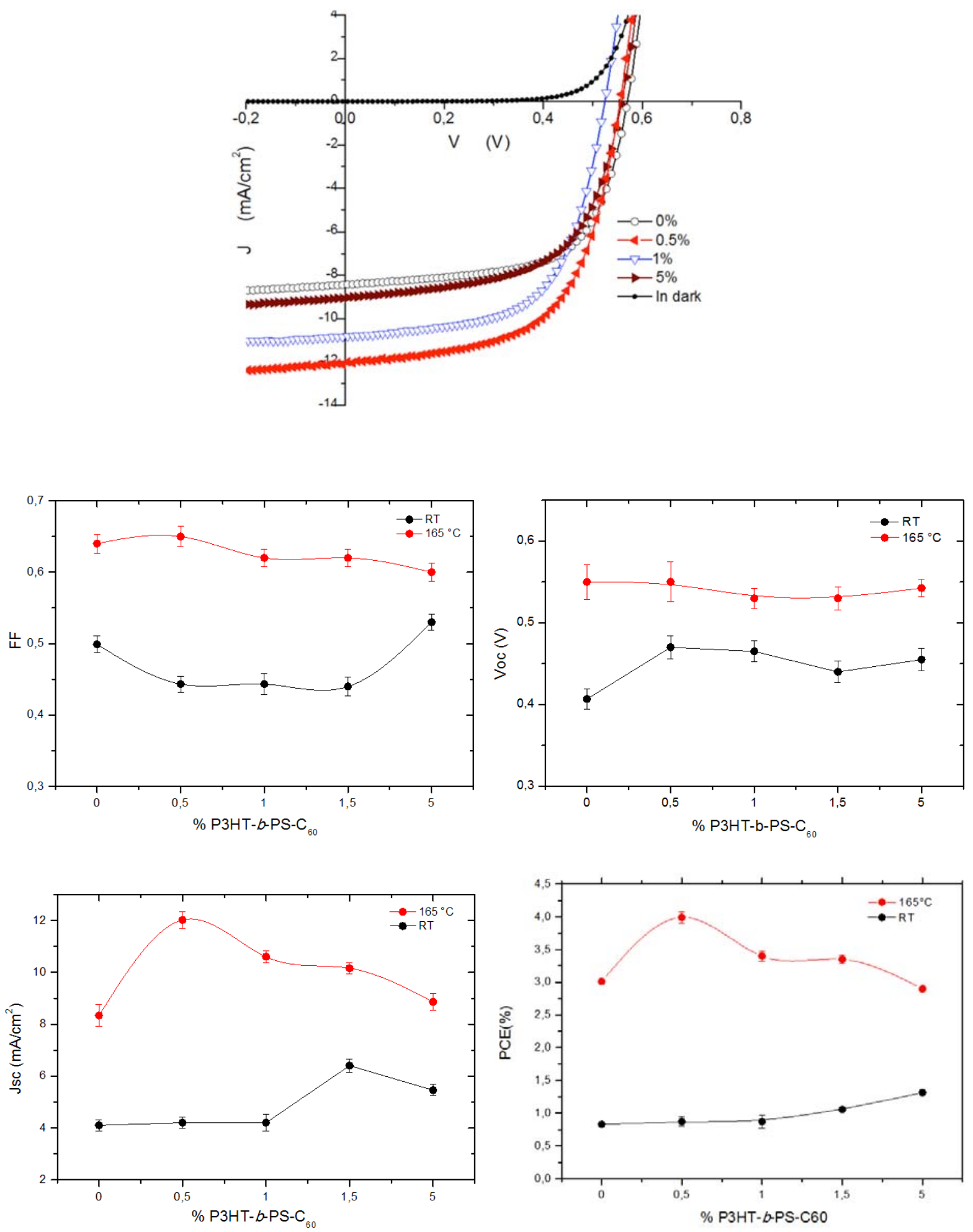

Figure 9. Photovoltaic characteristics of P3HT:PCBM blended with various \%wt of P3HT- $b$ PS- $b$ - $\mathrm{C}_{60}$ : (top) J-V characteristics; (below) $F F, V_{\mathrm{oc}}, J_{\mathrm{sc}}$, and PCE (\%), obtained with as-cast (black) and annealed (red) solar cells. Error bars were calculated from an average over 16 devices. 


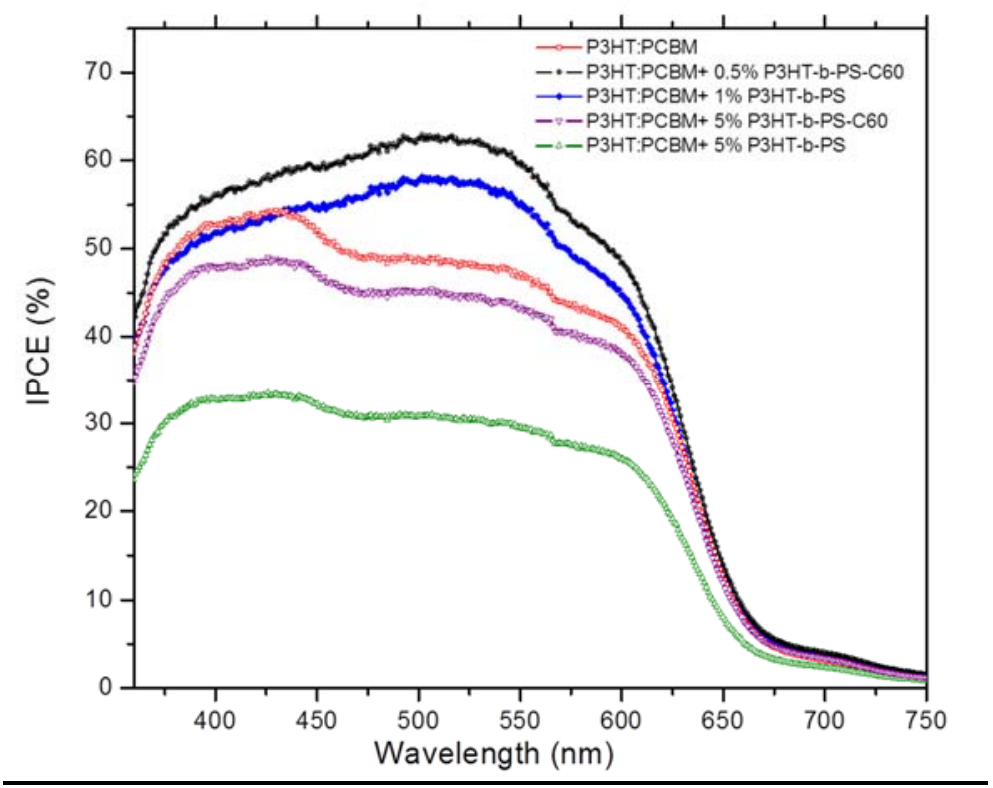

Figure 10. IPCE (\%) spectra of P3HT: PCBM with varying wt $\%$ fractions of added P3HT- $b$ PS- $\mathrm{C}_{60}$ (all following annealing at $165^{\circ} \mathrm{C}, 10 \mathrm{~min}$ ). 

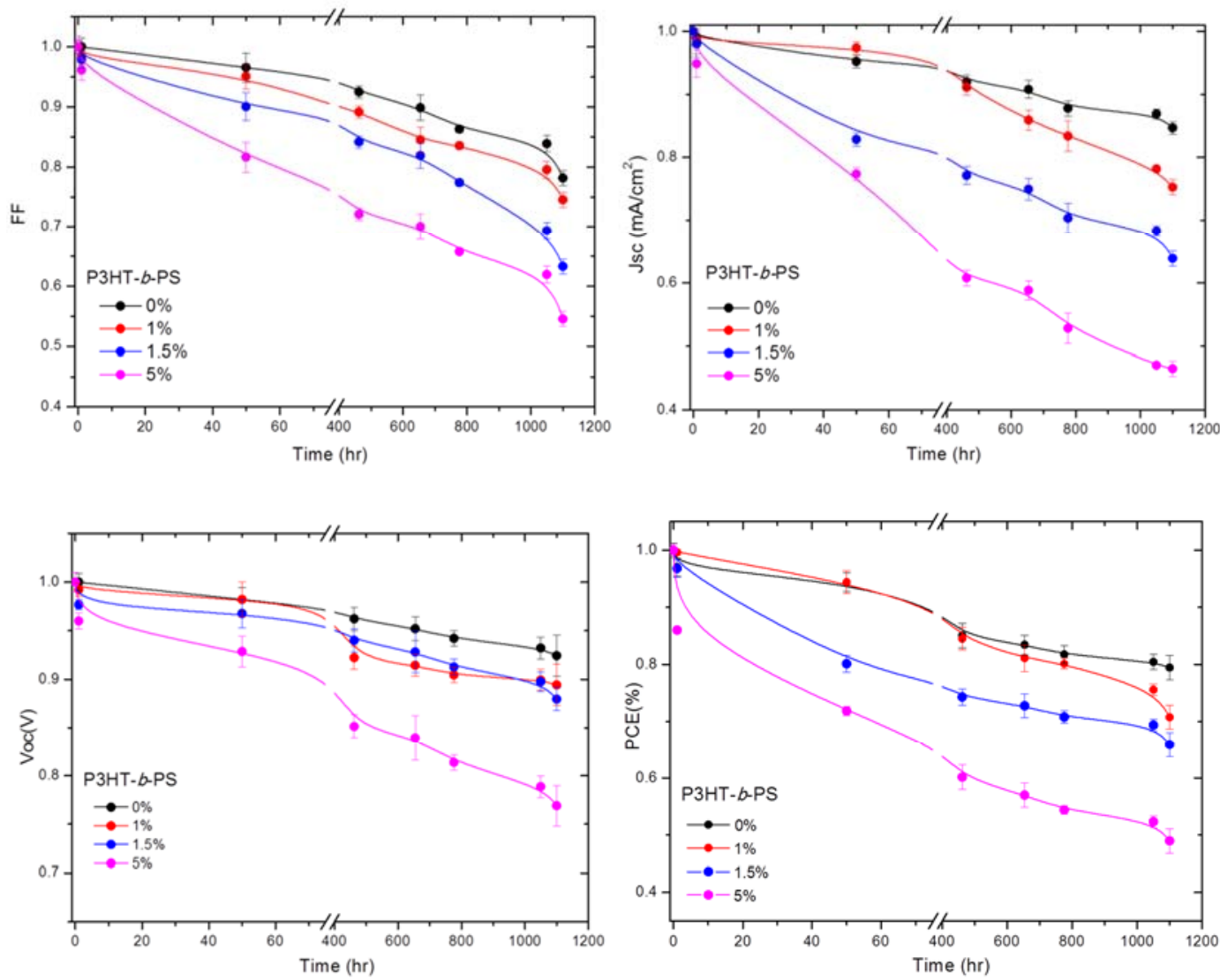

Figure 11. Decay curves under illumination of $V_{\mathrm{oc}}, F F, J_{\mathrm{sc}}$ and PCE (\%) of P3HT:PCBM based devices with varying wt $\%$ fractions of P3HT- $b$-PS. All performed in glove-box under nitrogen. 

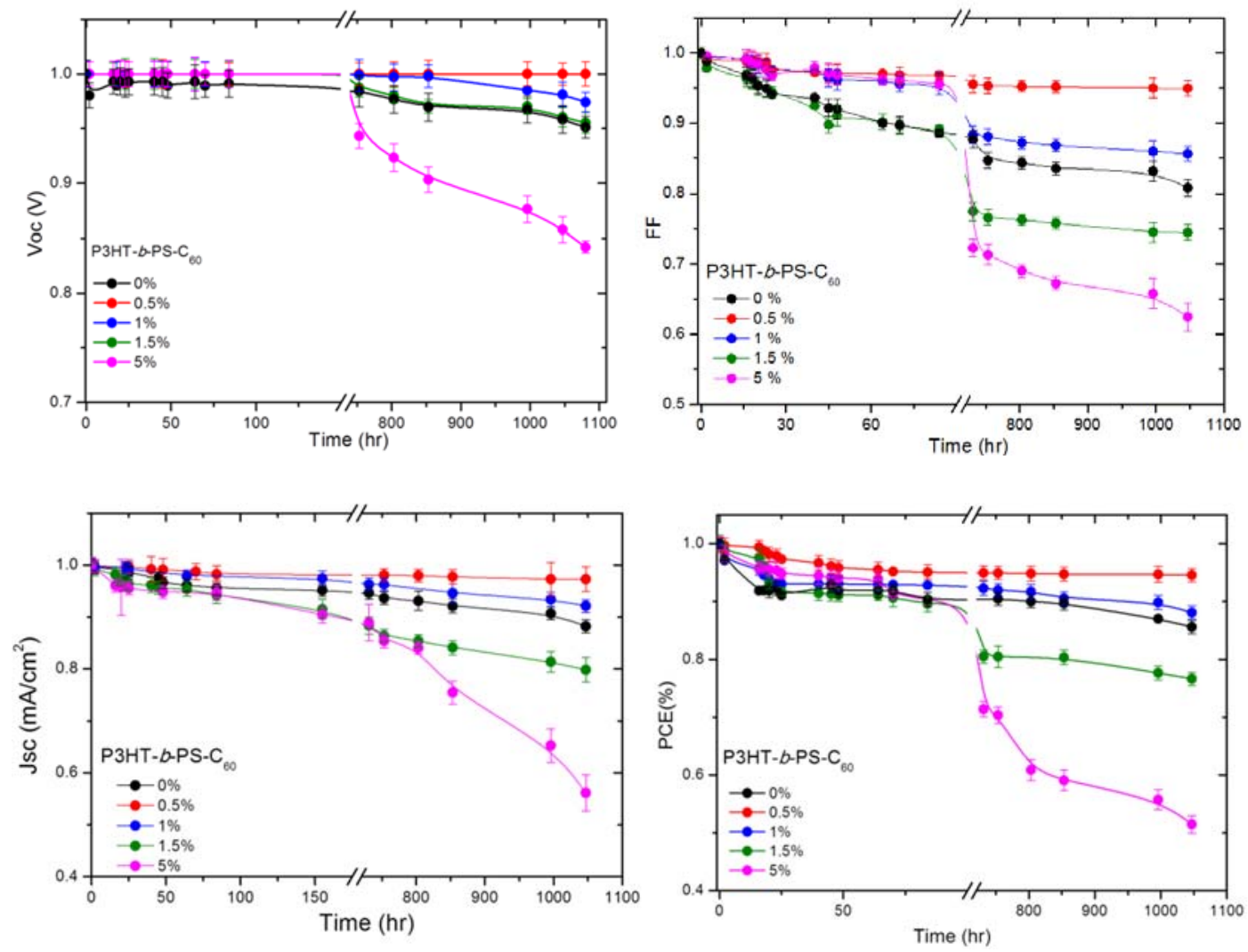

Figure 12. Decay curves under illumination of $V_{\mathrm{oc}}, F F, J_{\mathrm{sc}}$ and PCE (\%) of P3HT:PCBM based devices with varying $\mathrm{wt}^{\mathrm{t}} \%$ fractions of P3HT- $b$-PS-C 60 . All performed in glove-box under nitrogen. 


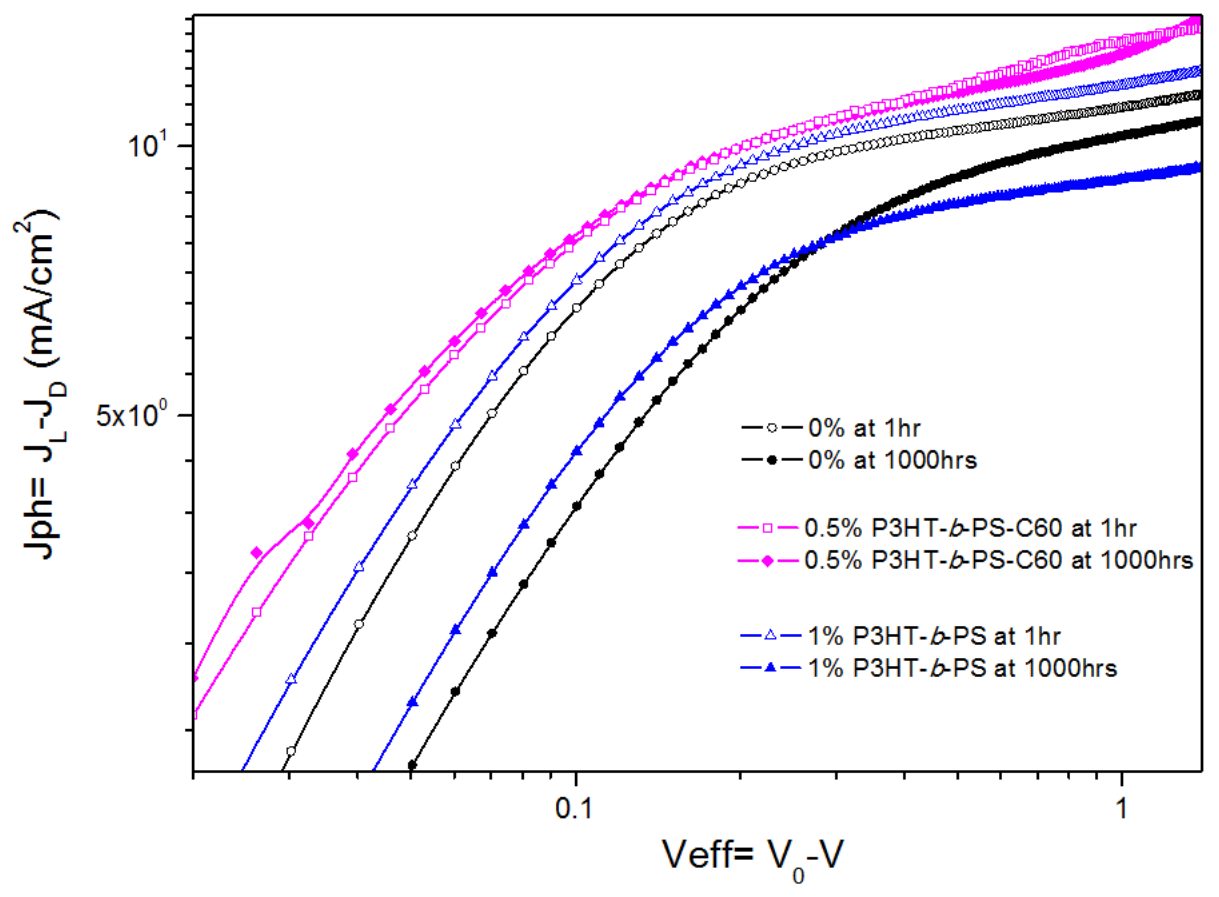

Figure 13. Experimental photocurrents after $1 \mathrm{~h}$ and $1000 \mathrm{~h}$ as a function of $V_{\text {eff }}$ for hero cells of: P3HT:PCBM reference (black curves, circular symbol); P3HT:PCBM and $1 \mathrm{wt} \%$ P3HT- $b$ PS (blue curves, triangle symbol); and P3HT:PCBM and 0.5wt\% P3HT- $b$-PS-C 60 (magenta curves, square symbol). 
Tables

\begin{tabular}{|c|c|c|c|c|}
\hline \multirow{2}{*}{ Polymer } & \multicolumn{2}{|c|}{ Crystallization } & \multicolumn{2}{c|}{ Melting } \\
\cline { 2 - 5 } & $\begin{array}{c}T_{c} \\
\left({ }^{\circ} \mathrm{C}\right)\end{array}$ & $\begin{array}{c}\text { Enthalphy } \\
\left(\mathrm{J} \mathrm{g}^{-1}\right)\end{array}$ & $\begin{array}{c}T_{m} \\
\left({ }^{\circ} \mathrm{C}\right)\end{array}$ & $\begin{array}{c}\text { Enthalphy } \\
\left(\mathrm{J} \mathrm{g}^{-1}\right)\end{array}$ \\
\hline P3HT & 203 & 12.5 & 231 & 16.5 \\
\hline P3HT- $b$-PS & 194 & 14.9 & 225 & 12.2 \\
\hline P3HT- $b$-PS-C60 & 192 & 13.0 & 222 & 6.5 \\
\hline
\end{tabular}

Table 1. Results of DSC characterisation of P3HT, P3HT- $b$-PS and P3HT- $b$-PS-C60. 


\begin{tabular}{|l|c|c|c|c|c|c|}
\hline \multirow{2}{*}{ Characteristics } & \multicolumn{7}{|c|}{ P3HT-b-PS (wt\%) } \\
\cline { 2 - 7 } & $\mathbf{0}$ & $\mathbf{0 . 5}$ & $\mathbf{1}$ & $\mathbf{1 . 5}$ & $\mathbf{2 . 5}$ & $\mathbf{5}$ \\
\hline$V_{\mathrm{oc}}(\mathrm{V})$ & 0.55 & 0.54 & 0.54 & 0.56 & 0.545 & 0.54 \\
\hline$J_{\mathrm{sc}}\left(\mathrm{mA} \mathrm{cm}{ }^{-2}\right)$ & $8.7 \pm 0.1$ & 10.1 & 11 & 9.3 & 8.5 & 7.85 \\
\hline$F F$ & 0.62 & 0.56 & 0.61 & 0.60 & 0.59 & 0.57 \\
\hline PCE $(\%)$ & 2.9 & 3.08 & 3.7 & 3.17 & 2.73 & 2.41 \\
\hline$R_{\mathrm{S}}\left(\Omega \mathrm{cm}^{-2}\right)$ & 8 & 7.8 & 6 & 9 & 20 & 30 \\
\hline$R_{\mathrm{sh}}\left(\Omega \mathrm{cm}^{-2}\right)$ & 660 & 665 & 669 & 660 & 690 & 770 \\
\hline Thickness $(\mathrm{nm})$ & $100( \pm 1)$ & $100( \pm 1)$ & $101( \pm 1)$ & $102( \pm 1)$ & $104( \pm 2)$ & $105( \pm 2)$ \\
\hline$R M S(\mathrm{~nm})$ & $7.0( \pm 0.5)$ & $4.0( \pm 0.2)$ & $3.5( \pm 0.1)$ & $3.8( \pm 0.1)$ & $4.1( \pm 0.1)$ & $5.0( \pm 0.2)$ \\
\hline
\end{tabular}

Table 2. $J-V$ characteristics of P3HT:PCBM blends mixed with various fractions (\%wt) of P3HT- $b$-PS. All results obtained from averages over four samples.

\begin{tabular}{|l|c|c|c|c|c|}
\hline \multirow{2}{*}{ Characteristics } & \multicolumn{5}{|c|}{ P3HT- $b$-PS- $b$-C60 $(\mathrm{wt} \%)$} \\
\cline { 2 - 6 } & 0 & $\mathbf{0 . 5}$ & 1 & 1.5 & 5 \\
\hline$V_{\mathrm{oc}}(\mathrm{V})$ & 0.56 & 0.54 & 0.51 & 0.53 & 0.54 \\
\hline$J_{\mathrm{sc}}\left(\mathrm{mA} \mathrm{cm}{ }^{-2}\right)$ & 8.40 & 12.02 & 10.5 & $10.16 \pm 0.30$ & 8.86 \\
\hline$F F$ & 0.64 & 0.60 & 0.61 & $0.60 \pm 0.002$ & 0.60 \\
\hline PCE $(\%)$ & 3.01 & 4.0 & 3.35 & 3.32 & 2.9 \\
\hline$R_{\mathrm{S}}\left(\Omega \mathrm{cm}^{-2}\right)$ & 9 & 7 & 8 & 9 & 20 \\
\hline$R_{\mathrm{sh}}\left(\Omega \mathrm{cm}^{-2}\right)$ & 690 & 740 & 680 & 660 & 660 \\
\hline Thickness $($ nm) & $100( \pm 1)$ & $100( \pm 1)$ & $101( \pm 1)$ & $102( \pm 1)$ & $107( \pm 1)$ \\
\hline RMS (nm) & $7( \pm 0.5)$ & $3.5( \pm 0.2)$ & $3.8( \pm 0.2)$ & $4( \pm 0.2)$ & $9( \pm 0.5)$ \\
\hline
\end{tabular}

Table 3. $J-V$ characteristics of P3HT:PCBM blends mixed with various fractions (\%wt) of $\mathrm{P} 3 \mathrm{HT}-b$-PS-C 60 . All results obtained from averages over four samples. 


\section{Table of Contents Graphic (ToC)}

Fullerene-capped Copolymers and P3HT: PCBM Bulk Heterojunctions: Device Stability and Efficiency Improvements

Mahfoudh Raïssi, Harikrishna Erothu, Emmanuel Ibarboure, Henri Cramail, Laurence Vignau, Eric Cloutet, Roger C. Hiorns

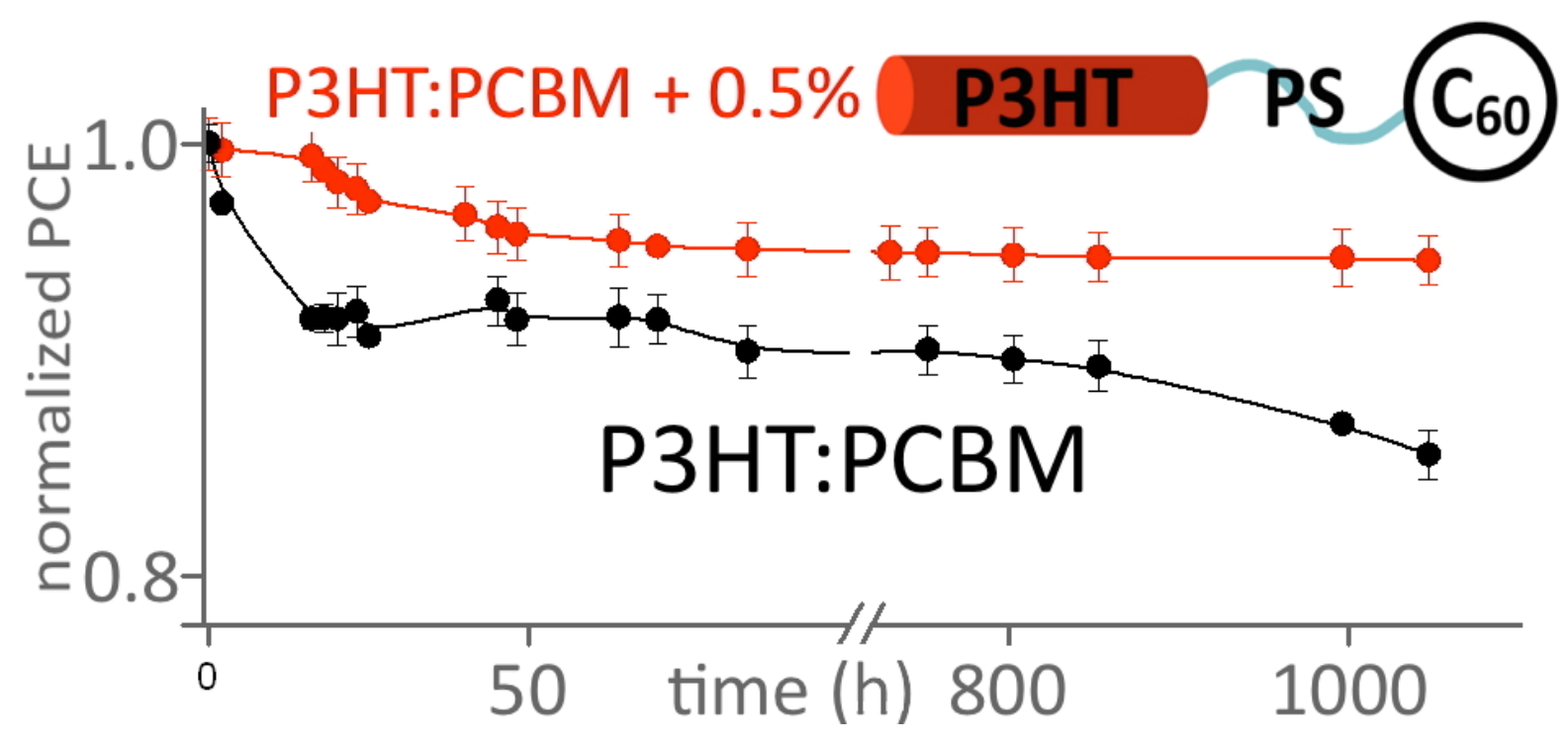

